\title{
INFLUENCE OF SURFACE MICROSTRUCTURE AND CHEMISTRY ON OSTEOINDUCTION AND OSTEOCLASTOGENESIS BY BIPHASIC CALCIUM PHOSPHATE DISCS
}

\author{
N.L. Davison ${ }^{1,2, *}$, J. Su${ }^{2}$, H. Yuan ${ }^{1,2,3}$, J.J.J.P. van den Beucken ${ }^{4}$, J.D. de Bruijn ${ }^{1,2,5}$ and F. Barrère-de Groot ${ }^{2}$
}

\begin{abstract}
${ }^{1}$ MIRA Institute for Biomedical Technology and Technical Medicine, University of Twente, Enschede, The Netherlands

${ }^{2}$ Xpand Biotechnology BV, Bilthoven, The Netherlands

${ }^{3}$ College of Physical Science and Technology, Sichuan University, Chengdu, Sichuan, P.R. China

${ }^{4}$ Department of Biomaterials, Radboud University Medical Centre, Nijmegen, The Netherlands

${ }^{5}$ School of Engineering and Materials Science (SEMS), Queen Mary University of London, London, UK
\end{abstract}

\begin{abstract}
It has been reported that surface microstructural dimensions can influence the osteoinductivity of calcium phosphates (CaPs), and osteoclasts may play a role in this process. We hypothesised that surface structural dimensions of $\leq 1 \mu \mathrm{m}$ trigger osteoinduction and osteoclast formation irrespective of macrostructure (e.g., concavities, interconnected macropores, interparticle space) or surface chemistry. To test this, planar discs made of biphasic calcium phosphate (BCP: $80 \%$ hydroxyapatite, $20 \%$ tricalcium phosphate) were prepared with different surface structural dimensions - either $1 \mu \mathrm{m}$ (BCP1150) or 2-4 $\mu \mathrm{m}$ (BCP1300) - and no macropores or concavities. A third material was made by sputter coating BCP 1150 with titanium (BCP1150Ti), thereby changing its surface chemistry but preserving its surface structure and chemical reactivity. After intramuscular implantation in 5 dogs for 12 weeks, BCP1150 formed ectopic bone in 4 out of 5 samples, BCP1150Ti formed ectopic bone in 3 out of 5 samples, and BCP1300 formed no ectopic bone in any of the 5 samples. In vivo, large multinucleated osteoclast-like cells densely colonised BCP1150, smaller osteoclast-like cells formed on BCP1150Ti, and osteoclast-like cells scarcely formed on BCP1300. In vitro, RAW264.7 cells cultured on the surface of BCP1150 and BCP1150Ti in the presence of osteoclast differentiation factor RANKL (receptor activator for $N F-\kappa B$ ligand) proliferated then differentiated into multinucleated osteoclast-like cells with positive tartrate resistant acid phosphatase (TRAP) activity. However, cell proliferation, fusion, and TRAP activity were all significantly inhibited on BCP1300. These results indicate that of the material parameters tested - namely, surface microstructure, macrostructure, and surface chemistry - microstructural dimensions are critical in promoting osteoclastogenesis and triggering ectopic bone formation.
\end{abstract}

Keywords: Biphasic calcium phosphate, topography, microstructure, osteoclast, osteoinduction.

*Address for correspondence:

Noel L. Davison

Xpand Biotechnology

Professor Bronkhorstlaan 10 Bldg 48

3723 MB Bilthoven

The Netherlands

Telephone Number: +31 302297280

FAX Number: +31 302297299

E-mail: noel.davison@gmail.com

\section{Introduction}

Certain calcium phosphates (CaPs) can induce de novo bone formation without exogenous stem cells or growth factors, making them particularly attractive for use as bone graft substitutes (Ripamonti, 1991; Yuan et al., 2010). Although the material parameters and biological signalling necessary to induce de novo bone formation are unclear, osteoinductive CaPs developed by different groups seem to share similar surface structure, specifically surface topographical features on a (sub)micron-scale. For instance, hydroxyapatite (HA) with surface micrograins and micropores induced ectopic bone formation in dogs and goats, but HA with a denser surface of large, fused grains and few micropores did not (Habibovic et al., 2005b; Yamasaki and Sakai, 1992; Yuan et al., 1998; Yuan et al., 1999). Similarly, microstructured biphasic calcium phosphate (BCP) - a mixture of HA and tricalcium phosphate (TCP) - induced de novo bone formation in the muscle of sheep (Le Nihouannen et al., 2005), goats (Habibovic et al., 2005b; Yuan et al., 2002), and dogs (Yuan et al., 2010); however, BCP with larger grains and fewer micropores induced less bone formation (Yuan et al., 2010) or in other cases none at all (Habibovic et al., 2006b). More recently, the dimensions of surface microstructure have also been shown to be important for osteoinduction - for instance, TCP with submicron-scale surface structure consistently stimulated de novo bone formation in dog muscle, while TCP with micron-scale surface structure was not at all osteoinductive (Davison et al., 2014b; Zhang et al., 2014). Surface microstructure may also be critical in triggering osteoinduction by other biomaterials such as titanium (Fujibayashi et al., 2004; Fukuda et al., 2011).

Macroscale features of osteoinductive biomaterials such as interconnected macropores, particle size, and surface concavities have also been previously speculated to be "essential" and "requisite" for de novo bone formation (Habibovic et al., 2005a; Habibovic et al., 2005b; Magan and Ripamonti, 1996; Yuan et al., 2002). However, extensive de novo bone can also form in the intramuscular space between non-macroporous, microporous $\mathrm{CaP}$ particles (Yuan and de Bruijn, 2011). Thus, it is still unclear if interparticle space along with microstructure is necessary for osteoinduction or if de novo bone can also form on a macroscopically flat surface.

The physicochemical properties of CaPs are also theorised to be crucial for osteoinduction through the formation of a crystalline carbonate apatite surface layer after implantation (Daculsi et al., 1989; LeGeros, 2008). 
The solubility of a given $\mathrm{CaP}$ (e.g., the HA/TCP ratio in the case of $\mathrm{BCP}$ ), as well as its microstructure (e.g., surface micropore and crystal grain size) contribute to this mineralised surface layer by modulating the dissolution/ reprecipitation of calcium and phosphate ions in body fluid (Daculsi et al., 1990). The biological relevance of surface reactivity and a precipitated layer of carbonate apatite is speculated to be either a direct physicochemical trigger for osteogenesis (i.e., the differentiation of bone forming osteoblasts from uncommitted precursors) through elevated local calcium and phosphate levels (Barradas et al., 2013; Beck et al., 2000; Syed-Picard et al., 2013), or a biomimetic template for bone deposition following osteoblast differentiation by another means (LeGeros, 2008). However, surface reactivity and carbonate apatite precipitation may only be a permissive factor in osteoinduction, not an osteogenic trigger. Taking the case of osteoinductive titanium as an example, Fujibayashi et al. (2004) reported that although both titanium mesh cylinders and porous blocks formed an apatite layer in simulated body fluid in vitro after thermochemical treatment, only the porous blocks induced ectopic bone formation - potentially due to more complex surface topography (Fujibayashi et al., 2004). Because surface reactivity and physical topography can both influence osteoblast differentiation but are linked to surface architecture, it is currently unknown which, if either, material property plays a prevailing role in osteoinduction (Curran et al., 2006; Habibovic et al., 2006a; Vlacic-Zischke et al., 2011; Zhao et al., 2007).

Alternatively, osteoinduction may depend on (pre-) osteoclast activity for osteogenic signals rather than intrinsic physicochemical signals originating from the material itself (Baslé et al., 1993; Gauthier et al., 2005; Malard et al., 1999). In support of this theory, it has been reported that osteoclastogenesis precedes osteoinduction by microstructured TCP by several weeks (Akiyama et al., 2011; Kondo et al., 2006), and osteoclast depletion limits (Ripamonti et al., 2010) or completely blocks de novo bone formation by osteoinductive CaPs (Davison et al., 2014a). Recently, we reported a clear link between TCP microstructure, osteoclastogenesis, and subsequent de novo bone formation (Davison et al., 2014a; Davison et al., 2014b). However, (pre-)osteoclast differentiation and activity is influenced by multiple substrate parameters including surface nano-/microroughness (Makihira et al., 2007; Webster et al., 2001), solubility (Benahmed et al., 1996; Yamada et al., 1997), and the accompanied release of nano-/microparticulate (Fellah et al., 2007; Velard et al., 2013), so it is currently unknown if this link also holds true for less resorbable materials like BCP or titanium.

Given the present knowledge, we hypothesised that surface structure is the preeminent material factor responsible for the formation of both osteoclast-like cells and de novo bone. To evaluate this, two BCPs with different surface structure were prepared in the form of planar, non-macroporous discs, thus eliminating the effects of interconnected macropores, concavities, or interparticle space. To evaluate whether the surface chemistry contributes to osteoinductivity, $\mathrm{BCP}$ was also surface coated with titanium. Disc constructs were implanted in the dorsal muscle of dogs, the classical model for evaluating osteoinduction, and the formation of de novo bone and multinucleated osteoclast-like cells was analysed by histology. The effects of surface structure and chemistry on osteoclastogenesis were further evaluated in vitro using the RAW264.7 pre-osteoclast cell line, as previously described (Davison et al., 2014b). Osteoclast differentiation, survival and morphology were measured and quantitatively compared using several biochemical, histological and morphological techniques.

\section{Materials and Methods}

\section{Preparation and characterisation of $\mathrm{BCP}$}

BCP powder composed of $80 \% \mathrm{HA} / 20 \% \beta$-TCP was prepared by wet precipitation as described elsewhere (Yuan et al., 2002). The powder was foamed with diluted $\mathrm{H}_{2} \mathrm{O}_{2}$ $(0.1 \%)$ (Merck, Schiphol-Rijk, Netherlands) at $60{ }^{\circ} \mathrm{C}$ to produce microporous green bodies and then dried. The dry green bodies were subsequently sintered at $1150^{\circ} \mathrm{C}$ or $1300{ }^{\circ} \mathrm{C}$ for $8 \mathrm{~h}$ to achieve surface micro-grains and pores (BCP1150) or larger fused grains and few micropores (BCP1300). Ceramic discs $(\varnothing 9 \times 1 \mathrm{~mm})$ were machined from the ceramic bodies using a lathe and a diamond saw microtome (Leica SP1600). Discs were ultrasonically cleaned in successive baths of acetone, ethanol and deionised water for $15 \mathrm{~min}$, and then dried at $60{ }^{\circ} \mathrm{C}$.

To obtain a different surface chemistry while preserving the surface microstructure, BCP1150 discs were sputter coated with titanium (BCP1150Ti) using a radiofrequency magnetron unit (Edwards ESM 100) as previously described (Wolke et al., 1998). Both sides of the discs were coated for $15 \mathrm{~min}$ at $200 \mathrm{~W}$, resulting in a visually complete layer of titanium roughly $50 \mathrm{~nm}$ thick. The elemental composition and distribution of the titanium coating was verified using electron dispersive spectroscopy (EDS), as previously described (Bongio et al., 2013). Briefly, samples were affixed to metal stubs and scanned by a scanning electron microscope (Philips XL30) equipped with an energy dispersive spectrometer (EDAX, Ametek). The distribution of elements of interest (Ca, P and Ti) was analysed and visually displayed. The associated error for all the EDS analyses was calculated to be less than $10 \%$.

Surface structure of the materials was characterised by scanning electron microscopy (SEM) (JEOL JSM-5600) after sputter coating with gold for $90 \mathrm{~s}$ (JEOL JFC 1300). Surface grain and pore size were quantified in scanning electron micrographs (magnification: $5000 \times, n=3$ random locations) by measuring the vertical distance across the features $(n>50)$ in Image J software (NIH, Bethesda, MD, USA).

Crystal chemistry of the materials was analysed by $\mathrm{X}$-ray diffraction (Rigaku Miniflex II) scanning the range $2 \theta=25-45^{\circ}\left(\right.$ step size $=0.01^{\circ}$, rate $\left.=1^{\circ} \mathrm{min}^{-1}\right)$ as previously described (Davison et al., 2014b). The surface reactivity of the discs was analysed in simulated physiologic solution (SPS) (50 mM HEPES, $140 \mathrm{mM} \mathrm{NaCl}$, and $0.4 \mathrm{mM} \mathrm{NaN}_{3}$ for sterility; all from Sigma Aldrich, Saint Louis, MO, USA) at $\mathrm{pH} 3$ and $\mathrm{pH} 7$. Discs $(n=3)$ were incubated in 
SPS ( $8 \mathrm{~mL})$ in a tissue culture multiwell plate incubated at $37{ }^{\circ} \mathrm{C}, 5 \% \mathrm{CO}_{2}$ for $7 \mathrm{~d}$ with gentle shaking. The solution was sampled and refreshed with the same amount $(100 \mu \mathrm{L})$ after $10 \mathrm{~min}, 1,2,4 \mathrm{~h}, 1,4$ and $7 \mathrm{~d}$. Calcium and phosphate released into the solution were quantified using QuantiChrom (BioAssay System, Hayward, CA, USA) and PhoshoWorks (AAT BioQuest, Sunnyvale, CA, USA) colorimetric assay kits, respectively, following the manufacturers' instructions. Absorbance was detected using a Zenyth 3100 multimode spectrophotometer.

\section{In vivo study of osteoinduction by BCP constructs Implantation of sandwich constructs}

BCP constructs were implanted in the dorsal muscle of dogs to test their capacity to form ectopic bone. BCP constructs were made by gluing (Cyanoacrylate "Superglue", Pertex, Cornwall, UK) two discs together with two strips of nylon wire $(\sim 0.7 \mathrm{~mm})$ in between to create a central gap (Fig. 3A). "Sandwich" shaped constructs were sterilised by gamma irradiation ( $>25 \mathrm{kGy}$ ) prior to implantation.

All surgery was conducted at the Animal Centre of Sichuan University in conformance with the institutional animal ethics committee's guidelines. Sterile BCP constructs were implanted in the dorsal muscle of healthy male mongrel dogs ( $n=5$ dogs, $1-4$ years, $10-15 \mathrm{~kg}$ ) for 12 weeks. Animals were first given general anaesthesia by abdominal injection of sodium pentobarbital $\left(30 \mathrm{mg} \mathrm{kg}^{-1}\right.$ body weight) and constructs were implanted into paraspinal muscle pockets created by scalpel incision and blunt dissection. One construct of each material was implanted in each dog resulting in 3 constructs implanted per animal. Skin incisions were closed layer by layer with nonresorbable sutures for identification at harvest. Following surgery, the animals were given daily intramuscular injections of buprenorphine $(0.1 \mathrm{mg}$ per animal) for $2 \mathrm{~d}$ and penicillin $\left(40 \mathrm{mg} \mathrm{kg}^{-1}\right)$ for $3 \mathrm{~d}$ to relieve pain and prevent infection. Animals were allowed to undertake full activity and received a normal diet immediately after surgery.

\section{Sample harvest and histological processing}

At the end of 12 weeks, the animals were euthanised by abdominal injection of sodium pentobarbital $\left(60 \mathrm{mg} \mathrm{kg}^{-1}\right)$ and samples were immediately harvested and fixed in cold phosphate-buffered formalin solution, dehydrated in graded ethanol series, and embedded in methyl methacrylate (MMA) (LTI, Bilthoven, Netherlands) at room temperature. Histological sections $(\sim 30 \mu \mathrm{m})$ of the undecalcified samples were made using a Leica SP1600 microtome and stained en bloc with $1 \%$ methylene blue and $0.3 \%$ basic fuchsin solutions for histological analysis.

Stained histological sections were scanned using a Dimage Scan Elite 5400II slide scanner (Konica Minolta) for gross evaluation. Bone formation was analysed at $20 \times$ magnification using a light microscope (Nikon Eclipse E200). More than 10 sections per sample spanning more than half the construct were analysed for de novo bone formation by 2 investigators (ND and JS), and the number of samples positive for bone formation per the total number of samples implanted (i.e., bone incidence rate) was recorded.

\section{In vitro studies}

Culture of RAW264.7 osteoclasts and C2C12 myoblasts on $B C P$ discs

To model osteoclastogenesis in vitro, murine RAW264.7 macrophages (ECACC, Salisbury, UK) were cultured on the surface of BCP discs for up to $5 \mathrm{~d}$ in the presence of osteoclast differentiation factor RANKL (receptor activator for NF- $\kappa \mathrm{B}$ ligand) as described previously (Collin-Osdoby et al., 2003). RAW264.7 cells were first expanded in tissue culture flasks with basic medium composed of alpha MEM (Lonza, Breda, Netherlands), supplemented with $10 \%$ HyClone FetalClone I serum (Thermo Scientific, Waltham, MA, USA) and $1 \%$ penicillin-streptomycin (Life Technologies, Merelbeke, Belgium). At $75 \%$ confluence, cells were scraped loose from the tissue culture flasks, resuspended in basic medium supplemented with RANKL (40 ng mL $\mathrm{m}^{-1}$, Peprotech, London, UK), and seeded on BCP discs $\left(2 \times 10^{4}\right.$ cells cm$\left.~^{-2}\right)$. All discs were heat sterilised in a dry chamber at $200{ }^{\circ} \mathrm{C}$ for $2 \mathrm{~h}$ prior to cell culture.

RAW264.7 cells were cultured for $5 \mathrm{~d}$ with medium refreshment (basic medium + RANKL) after $1 \mathrm{~d}$. In our previous experience with this culture model (Davison et al., 2014b), cells begin to fuse and differentiate into osteoclasts by day 3 , continue fusing through day 4-5, and undergo apoptosis by day 6-7 (Collin-Osdoby et al., 2003; Takahashi et al., 2007). Therefore, biochemical assays focused on day 3-5 as the relevant period of osteoclastogenesis. Osteoclast culture experiments were repeated to confirm the results of the various assays described below.

C2C12 myoblasts were cultured on BCP discs to study the effects material properties on muscle cells. C2C12 cells were similarly expanded in basic medium, trypsinised at confluence, and cultured on BCP discs (seeding density $=2 \times 10^{4}$ cells $\mathrm{cm}^{-2}$ ) for $5 \mathrm{~d}$. All cells were cultured in a humidified incubator maintained at $37{ }^{\circ} \mathrm{C}$ and $5 \% \mathrm{CO}_{2}$.

\section{Cell viability, proliferation, and DNA content}

The AlamarBlue (AB) fluorescent assay (Life Technologies) was used to measure cell viability and proliferation (Nakayama et al., 1997) on BCP. AB measures the reductive activity inside living cells, and is commonly used in the literature as a more sensitive alternative to formazanbased cell viability assays such as MTT and XTT (Ahmed et al., 1994; Gloeckner et al., 2001). At various culture time points, cells were incubated with culture medium containing $5 \% \mathrm{AB}$ reagent for $2 \mathrm{~h}$ in culture conditions and then media samples were collected in a 96-well plate for fluorescent detection (excitation $=530 \mathrm{~nm}$, emission $=590 \mathrm{~nm}$ ) using a Zenyth Multimode plate reader. Cell proliferation can be measured by assaying cell viability over time (Nakayama et al., 1997). For this assay, the same procedure was followed except that AB-containing culture medium was removed and refreshed with normal culture medium, and then continuously cultured until the next time point. For viability and proliferation assays, $n=3$ culture replicates were measured.

DNA content was measured in the cell lysate using a CyQuant DNA detection kit (Life Technologies). After 3, 4 and $5 \mathrm{~d}$ culture on discs, adherent cells were rinsed in phosphate-buffered saline (PBS) and then freeze-thawed 
A
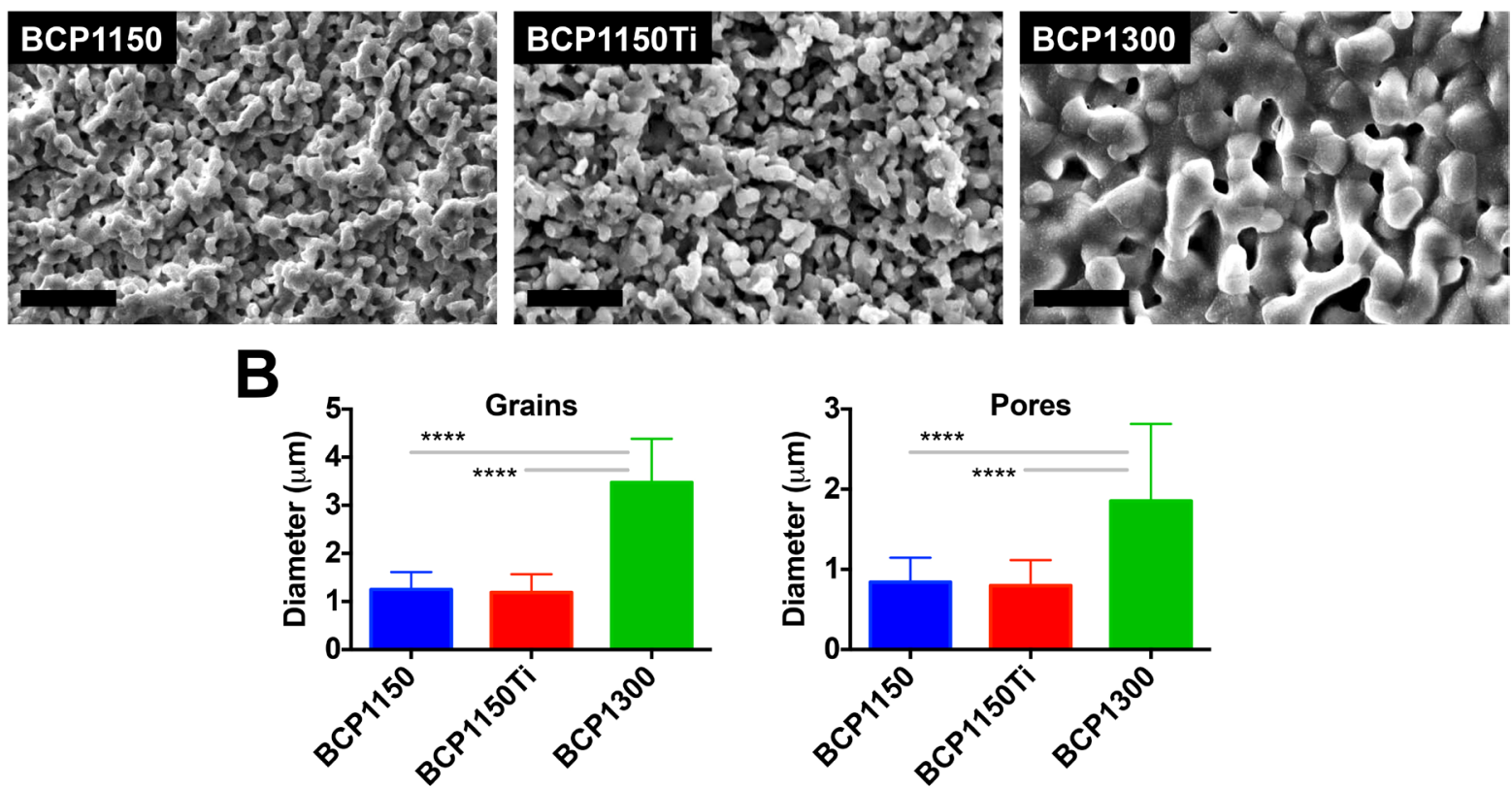

Fig. 1. Surface characterisation of BCP. Scanning electron micrographs show the difference in surface microstructure between BCP1150 and BCP1300 and the similarity between BCP1150 and BCP1150Ti with titanium coating $($ scale $=10 \mu \mathrm{m})(\mathbf{A})$. Surface grain and pore size $\leq 1 \mu \mathrm{m}$ of BCP1150 were unchanged by titanium coating; however, grains and pores of BCP1300 were significantly larger $(\mathbf{B}) . * * * *<0.0001$.

in CyQuant cell lysis buffer, as recommended by the manufacturer. Cell lysate was thoroughly homogenised and sampled from $n=3$ replicate discs for measurement using the kit. A Zenyth 3100 Multimode plate reader was used to detect the fluorescent signal of the assay.

Tartrate resistant acid phosphatase (TRAP) activity Tartrate resistant acid phosphatase (TRAP) activity, an enzyme marker of osteoclast differentiation (Halleen et al., 2001), was measured in RAW264.7 cells cultured on discs after 3, 4 and $5 \mathrm{~d}$ by both biochemical activity and cytochemical staining. TRAP activity in the cell lysate from $n=3$ culture replicates was quantified by conversion of $p$-nitrophenylphosphate to $p$-nitrophenol ( $\mathrm{pNP}$ ) in sodium acetate buffer ( $\mathrm{pH}$ 5.8) containing potassium sodium tartrate $(10 \mathrm{mM})$, as reported by Ljusberg et al. (1999). Cell lysate was obtained by first rinsing disc-adherent cells with PBS and then freeze-thawing in cell lysis buffer (0.1 M sodium acetate, $0.1 \%$ Triton X-100, pH 5.8). All reagents were purchased from Sigma Aldrich. Optical absorbance of the assay reaction was measured using a Zenyth multimode spectrophotometer. Absorbance was converted to $\mathrm{mM}$ pNP using a standard curve of $\mathrm{pNP}$ (Sigma Aldrich) and normalised to viable cell signal from AlamarBlue. TRAP was also visualised on $n=2$ disc replicates using a commercial staining kit (Leukocyte Acid Phosphatase Kit, Sigma Aldrich). Prior to staining, cells were briefly rinsed in PBS and fixed in acetone methanol solution as per the manufacturer's instructions. Images were captured using a Nikon SMZ800 stereomicroscope equipped with a Nikon camera.

\section{SEM of osteoclast morphology}

Osteoclast morphology was analysed by SEM. Cells cultured on discs $(n=2)$ were fixed in $2.5 \%$ glutaraldehyde, dehydrated in a graded ethanol series, and finally dried in hexamethyldisilazane (HMDS; Alfa Aesar, Karlsruhe, Germany). Dehydrated cells were then sputter coated with gold for enhanced imaging resolution. Osteoclast size was quantified in scanning electron micrographs (400× magnification), by calculating the mean surface area of cells at 3 random locations of replicate discs $(n=2)$ using automated threshold, edge detection, and particle analysis functions in ImageJ software (NIH), as previously described (Davison et al., 2014b). Only cells $>400 \mu \mathrm{m}^{2}$ were included in the analysis to safely exclude mononuclear cells.

\section{Statistical analysis}

Statistical comparisons were performed using One-way ANOVA and Tukey's post hoc tests; $p$ values $<0.05$ were considered significant. All statistical analyses were conducted in GraphPad Prism 6.0.

\section{Results}

\section{BCP characterisation}

BCP 1150 and BCP1300 with different surface microstructures were prepared by changing the sintering temperatures, as shown by SEM (Fig. 1A). Quantitatively, BCP1150 contained grains and pores sized $\leq 1 \mu \mathrm{m}$ in diameter but BCP1300 contained larger, fused grains 
Fig. 2. Chemical characterisation of BCP. The XRD spectra were equivalent for all three BCP materials (A). Chemical reactivity in simulated physiologic solution (SPS) showed that ion release of all three materials was equivalent at $\mathrm{pH} \mathrm{7,} \mathrm{but} \mathrm{slightly} \mathrm{faster} \mathrm{for}$ BCP1150 with and without titanium coating than BCP1300 at $\mathrm{pH} 3$ (B). Data represents the mean \pm S.D. of $n=3$ replicate discs, $p<0.0001$.

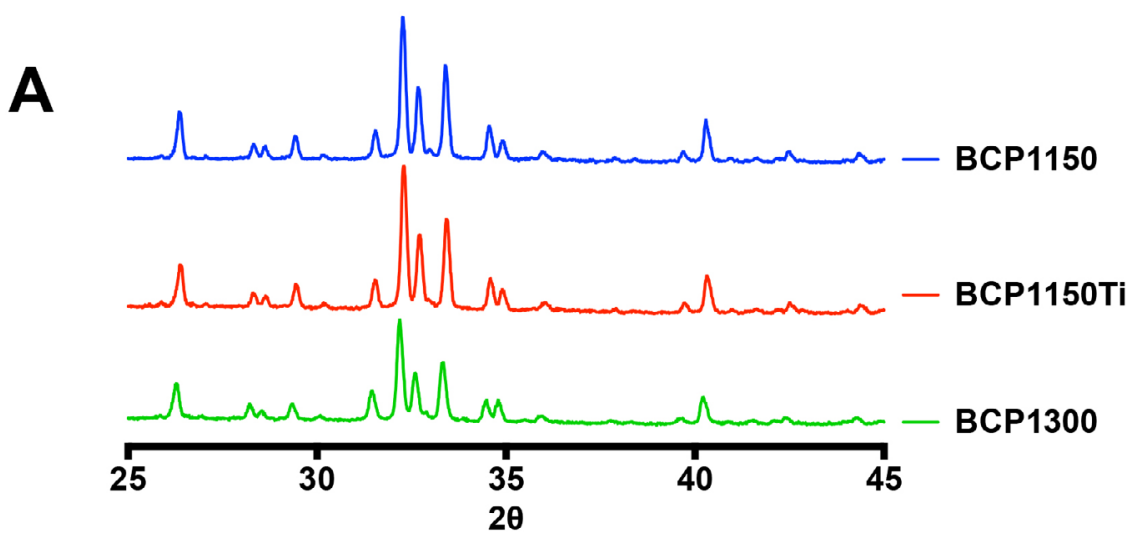

B
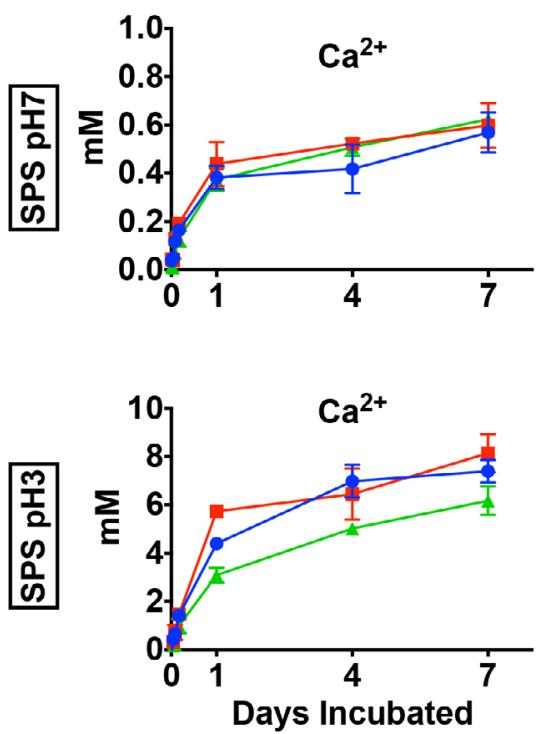
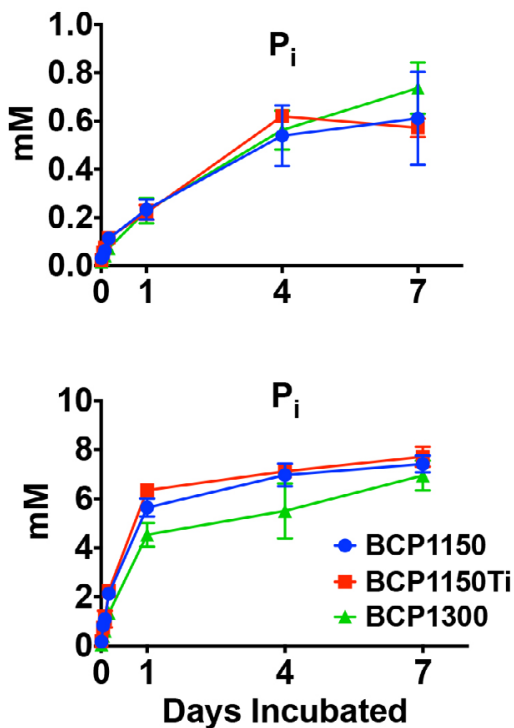

$(\sim 3 \mu \mathrm{m})$ and larger but fewer micropores $(\sim 2 \mu \mathrm{m})$ (Fig. $1 B)$ ). Because no macropore porogens were introduced during synthesis, neither material contained macropores or substantial concavities. Sputter coating BCP1150 with titanium (BCP1150Ti) did not visibly change the surface microstructure by SEM (Fig. 1A) or the size of the surface grains and pores (Fig. 1B) versus BCP1150.

The crystal chemistry of the materials was confirmed by X-ray diffraction (XRD) to be BCP containing 80 $85 \%$ HA and $15-20 \%$ TCP (Fig. 2A). Coating BCP 1150 with titanium did not substantially alter the XRD spectra. The surface reactivity of the materials was analysed by measuring calcium and phosphate ion release in simulated physiologic solution (SPS) at $\mathrm{pH} 7$ and $\mathrm{pH} 3$ (Fig. 2B). At neutral $\mathrm{pH}$, all three materials released similar amounts of ions over time, but at acidic $\mathrm{pH}$, ion release from $\mathrm{BCP} 1150$ and BCP1150Ti was higher than BCP1300, resulting from the increased surface area of the microstructure. There was no change in ion release by BCP 1150 with or without the titanium coating showing that the coating did not change the chemical reactivity of the material (Fig. 2B).

Sputter coating BCP1150 with titanium resulted in a visually homogenous layer on all sides of the discs (Fig. 3A). The titanium layer was analysed by EDS, which showed the homogeneously distributed titanium coating on the surface (Fig. 3B) that remained on the surface after implantation (Fig. 4). In summary, sputter coating BCP1150 with titanium resulted in a material
Table 1. Incidence rate of specimens containing de novo bone formation

\begin{tabular}{|c|c|c|}
\hline BCP1150 & BCP1150Ti & BCP1300 \\
\hline $4 / 5$ & $3 / 5$ & $0 / 5$ \\
\hline
\end{tabular}

with equivalent microstructure and chemical reactivity but different surface chemistry.

\section{In vivo results}

BCP sandwich constructs were implanted into the dorsal muscle of dogs for 12 weeks to study the effects of surface microstructure and chemistry on osteoinduction. A gap between the $\mathrm{BCP}$ discs was created using nylon wire spacers to allow tissue in-growth and bone formation (Fig. 5A). However, soft tissue formation in the space between the discs and around the nylon wires tended to be weak for all materials compared to tissue formation on the outer edges of the constructs (Fig. 5B).

The incidence of de novo bone formation was quantified by thorough analysis of histological sections. De novo bone formation was observed in 4 out of $5 \mathrm{BCP} 1150$ constructs, 3 out of 5 BCP1150Ti constructs, and 0 out of 5 BCP1300 constructs (Table 1). For BCP1150 and BCP1150Ti, bone was predominantly formed on the outer surfaces of the constructs (Fig. 6A) rather than on the inner surfaces of the central gap. Although stretches of bone were not thicker 


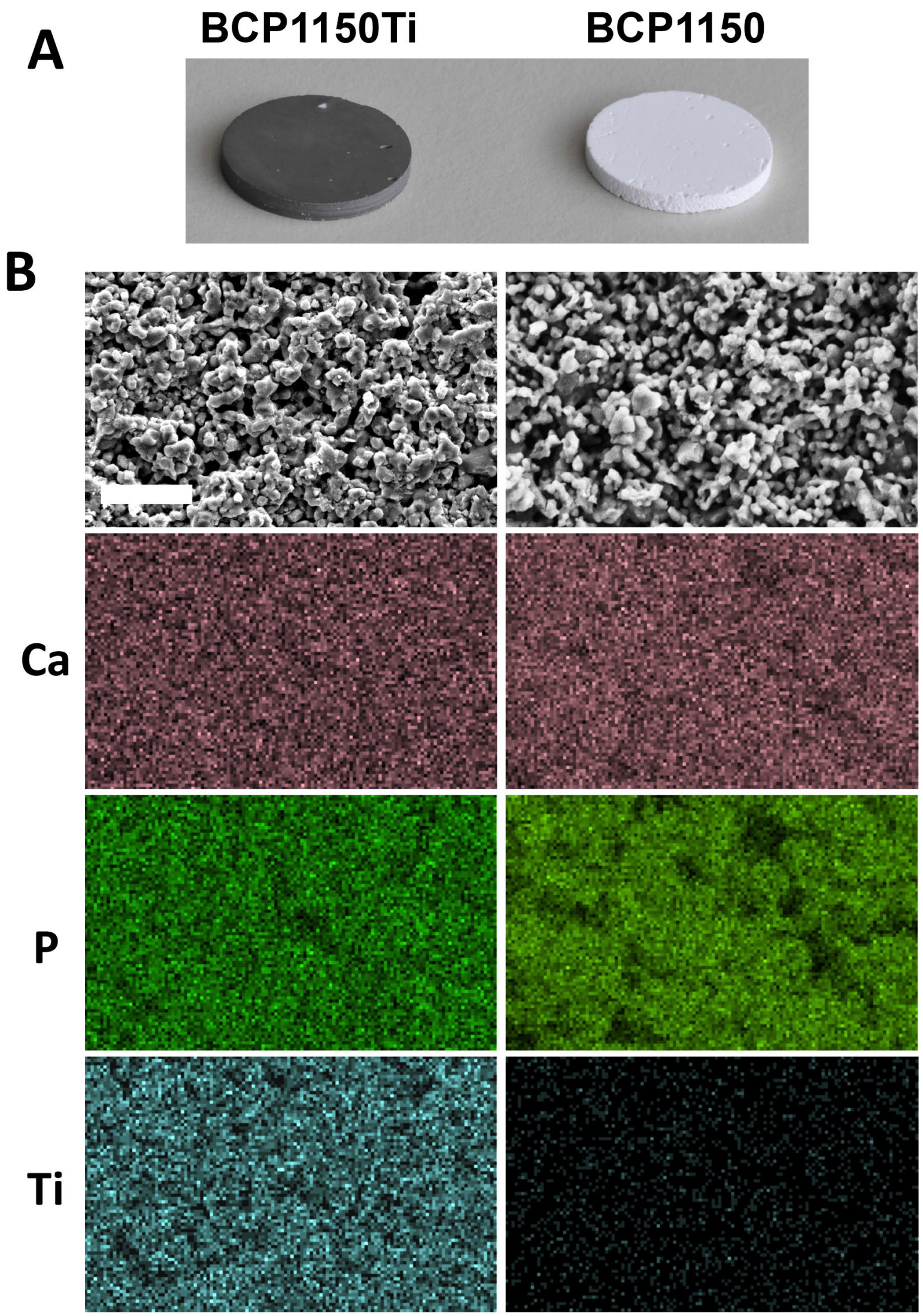

Fig. 3. Elemental analysis of BCP1150Ti by electron dispersive spectroscopy (EDS). (A) Overview images of BCP1150 and BCP1150Ti show that discs were appreciably devoid of concavities or macropores and that titanium coating uniformly covered the disc surfaces. (B) Elemental diffraction spectroscopy (EDS) analysis (2,000× magnification) shows titanium (Ti) on the surface of BCP1150Ti (left column) was evenly distributed and porous similar to the underlying substratum composed of calcium $(\mathrm{Ca})$ and phosphorus $(\mathrm{P})$. In comparison, BCP1150 (right column) depicted only background noise. Scale $=10 \mu \mathrm{m}$. 

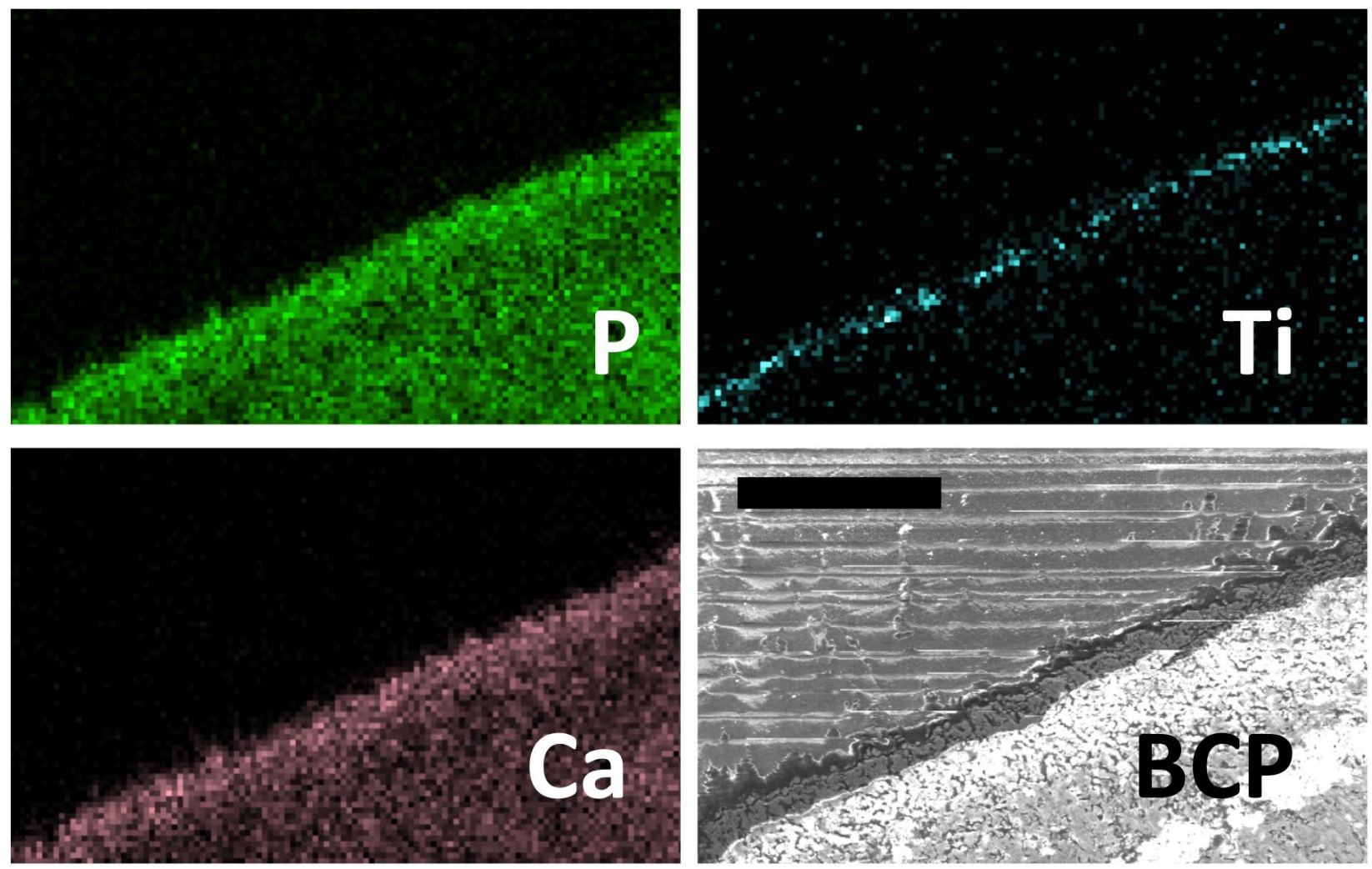

Fig. 4. Elemental analysis of BCP1150Ti explant. After 12 weeks intramuscular implantation, a thin layer of titanium was still intact on the edge of the BCP115Ti construct cross-section. Scale $=50 \mu \mathrm{m}$.

Fig. 5. Intramuscular implantation of $\mathrm{BCP}$ sandwich constructs. BCP sandwich constructs were made by gluing together two BCP discs with a central gap in between them using nylon wire spacers (A). Constructs were implanted in the dorsal muscle of dogs for 12 weeks and histological sections were stained with methylene blue and basic fuchsin (B). Overview images of crosssections taken through the middle of explants show soft tissue (pink, purple, blue) formation around the BCP constructs (brown, black) with limited tissue infiltration in the gap between the discs. Tissue often delaminated from the surface of BCP1300 constructs (black arrows), indicating weak tissue bonding. Note: few macropores or concavities were present in the discs. B, scale $=1 \mathrm{~mm}$.
A

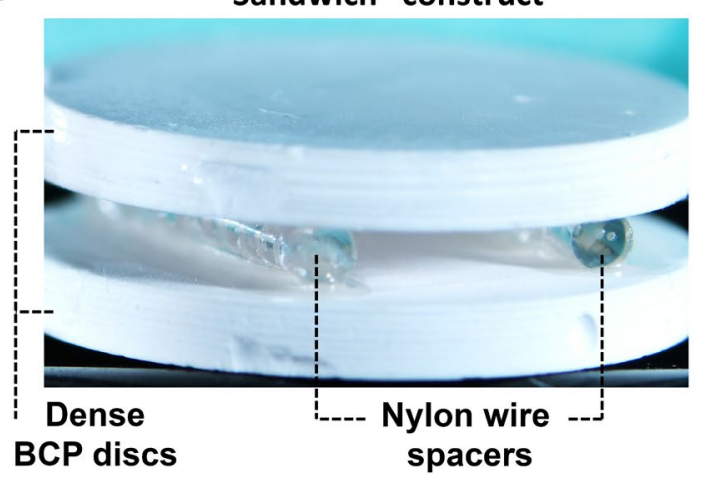

\section{B BCP1150}

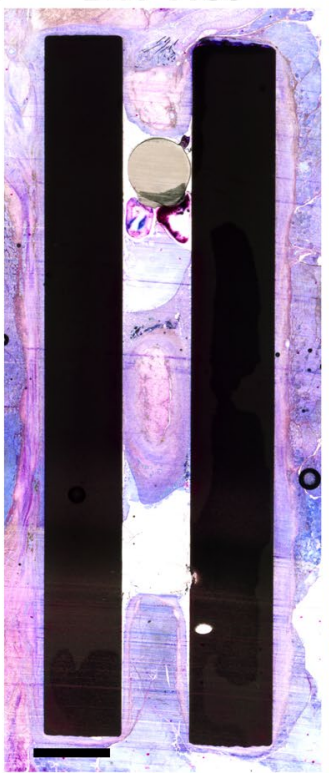

BCP1150Ti

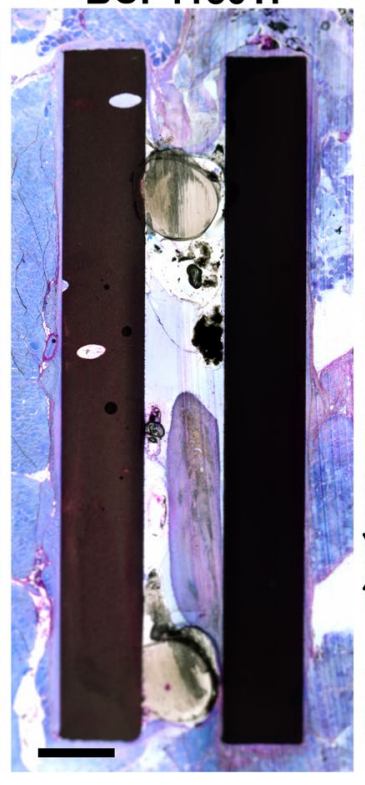

BCP1300

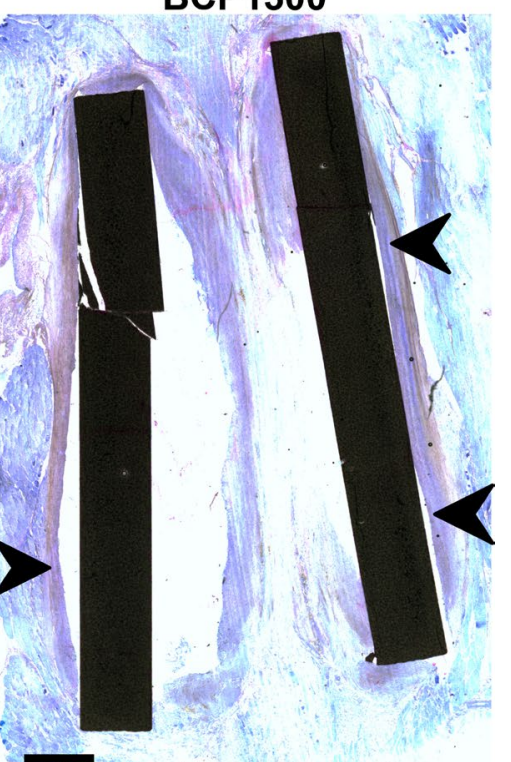



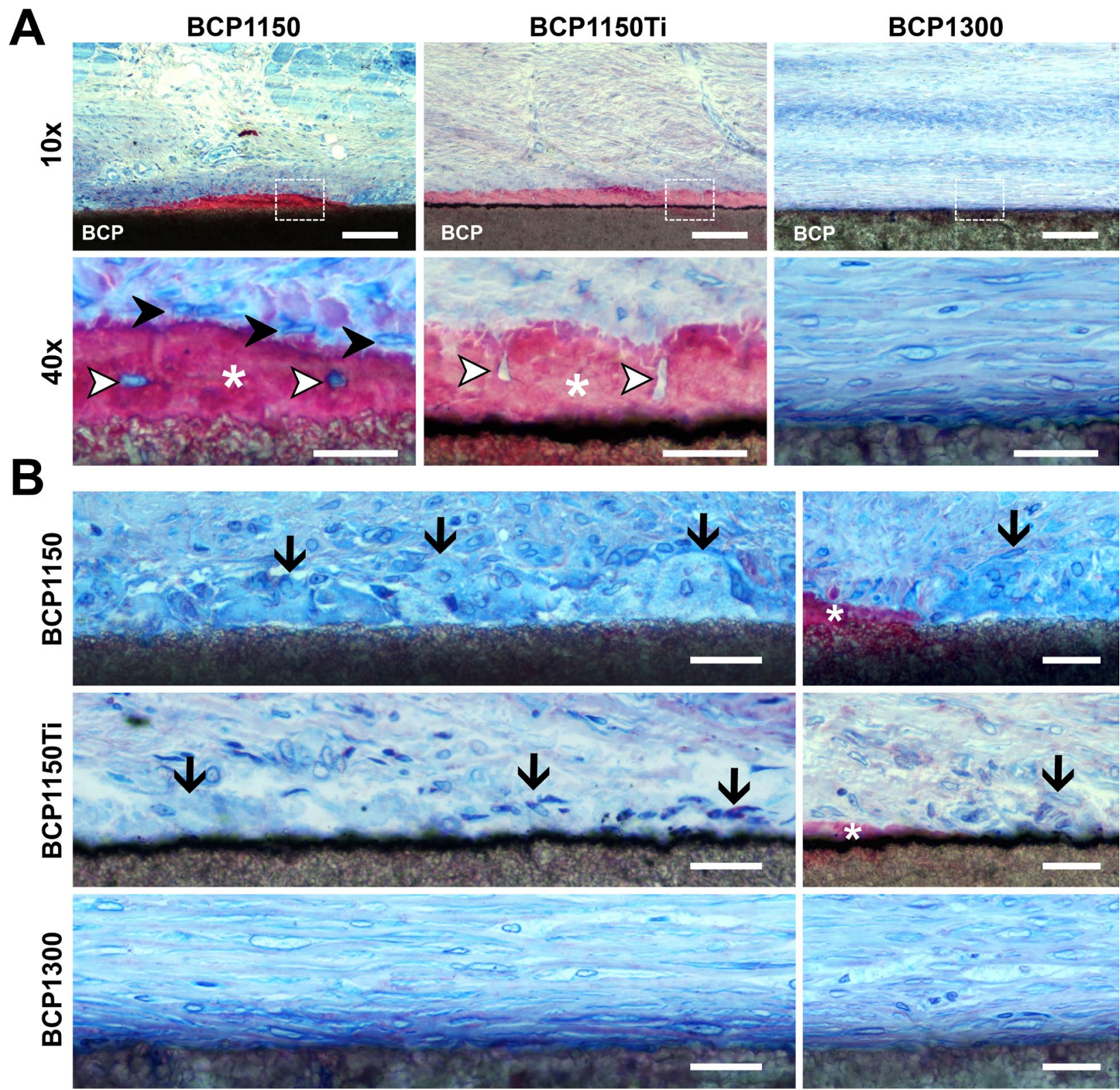

Fig. 6. Histology of intramuscularly implanted BCP sandwich constructs. (A) At 10× magnification of the outer surface of the constructs (top row), a thin layer of ectopic bone (red/pink) was evident on BCP1150 and BCP1150Ti, but only fibrous tissue (blue/purple) was present on BCP1300. Scale $=100 \mu \mathrm{m}$. At 40× magnification (bottom row), osteocytes (white arrowheads) resided in characteristic bone (asterisk) lacunae on the surface of both BCP1150 and BCP1150Ti. Flattened osteoblasts (black arrowheads) surrounded by condensing matrix flanked the ectopic bone formed on BCP1150. Scale $=25 \mu \mathrm{m}$. (B) Multinucleated cells (black arrows) formed on BCP1150 were larger and more densely organised than on BCP1150Ti, while no discernible multinucleated cells were present on the surface of BCP1300 (left column). Scale $=25 \mu \mathrm{m}$. Multinucleated osteoclast-like cells bordered ectopic bone on BCP1150 and BCP1150Ti; however, these cells appeared smaller and less fused on BCP1150Ti than on BCP1150 (right column). The intact titanium layer on BCP1150Ti was evident throughout the micrographs (thin black strip on the construct surface). Scale $=25 \mu \mathrm{m}$.

than $\sim 50 \mu \mathrm{m}$ and generally spanned less than several hundred $\mu \mathrm{m}$ long, cuboidal osteoblasts were seen forming new bone and osteocytes were present in bone lacunae (Fig. $6 \mathrm{~A})$. Bone area was not quantified by histomorphometry due to the small amounts present.

Multinucleated osteoclast-like cells extensively covered the surface of BCP1150, but were smaller and less organised on BCP1150Ti (Fig. 6B). For both materials, osteoclast-like cells adhered to the material adjacent to de novo formed bone. In contrast to $\mathrm{BCP} 1150$, with and without a titanium coating, BCP1300 was largely encapsulated by fibrous tissue and contained scarce multinucleated osteoclast-like cells (Fig. 6B).

\section{In vitro results}

\section{Cell viability and proliferation}

To further investigate the effects of BCP surface structure and chemistry on osteoclast-like cell formation, RAW264.7 macrophages were cultured on BCP discs and differentiated into osteoclast-like cells using RANKL. At day 3, 4 and 5, 


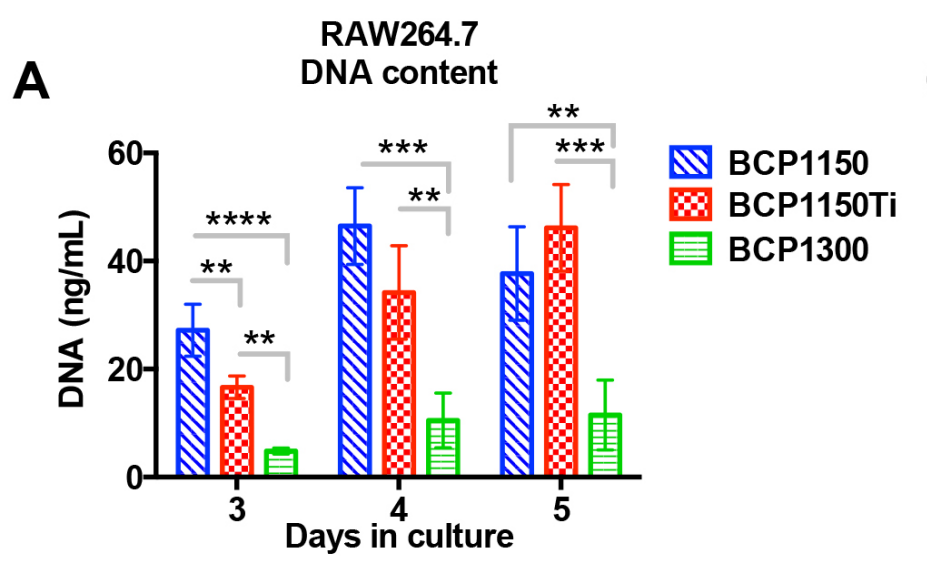

C

B

RAW264.7 Viability, day 5
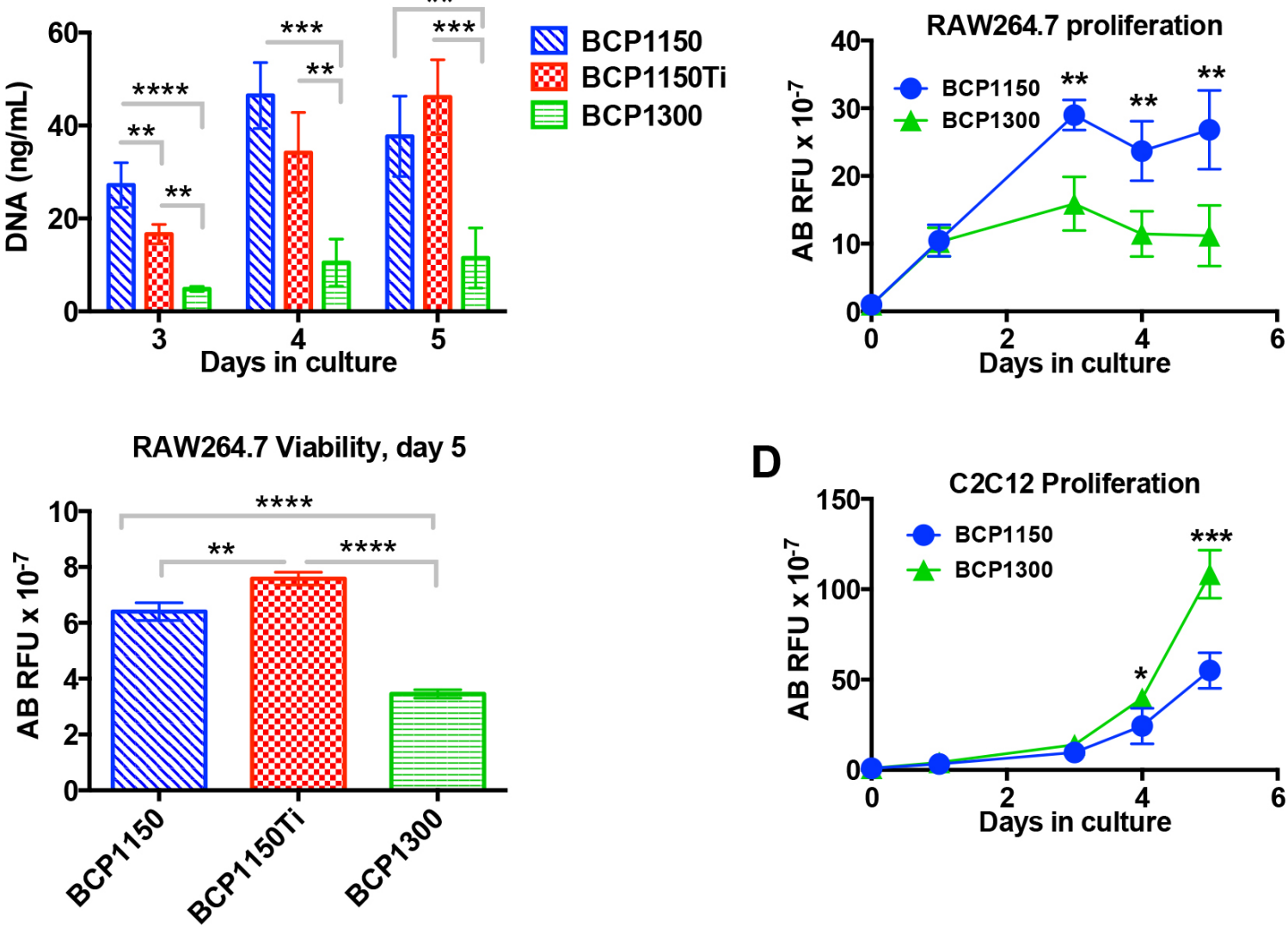

D

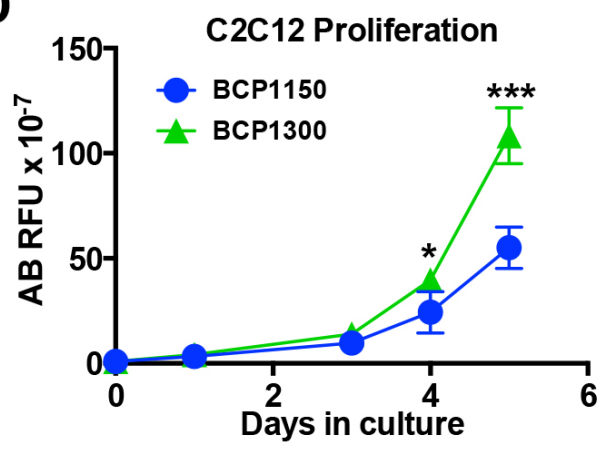

Fig. 7. Cell viability and proliferation on $\mathrm{BCP}$ in vitro. RAW264.7 cells were cultured on $\mathrm{BCP}$ discs in the presence of RANKL for $5 \mathrm{~d}$ to stimulate osteoclast formation. DNA content in the lysate from cells cultured on BCP1150 was significantly higher than on BCP1300 at day 3, 4 and 5. DNA content was different between BCP1150 and BCP1150Ti at day 3 and 4; however, they were equivalent by day 5 (A). At day 5 , osteoclast viability was also significantly higher on $\mathrm{BCP} 1150$ and $\mathrm{BCP} 1150 \mathrm{Ti}$ than on $\mathrm{BCP} 1300$, as measured by AlamarBlue $\mathrm{AB}$ ) metabolic indicator (AB $\mathrm{RFU}=\mathrm{AB}$ relative fluorescent units) $(\mathbf{B})$. Comparing the effects of only surface microstructure, RAW264.7 cells were again cultured in the presence of RANKL on BCP1150 and BCP1300 and cell viability was measured over time indicating cell proliferation. After 1 day, viability was equivalent between BCP1150 and BCP1300, but by days 3, 4 and 5 cells had proliferated on BCP1150 but not on BCP1300 (C). In contrast, $\mathrm{C} 2 \mathrm{C} 12$ myoblasts proliferated more on BCP1300 than on BCP1150 (D). Data represent the mean \pm S.D. of $n=3$ replicate discs. ${ }^{*} p<0.05, * * p<0.01$, $* * * p<0.001, * * * * p<0.0001$.

DNA content from cells cultured on BCP1150 was 3-5 times greater than on BCP1300 (day 3: $p<0.0001$; day 4: $p=0.0001$; day 5: $p=0.004$ ) (Fig. 7A). DNA content from cells cultured on BCP1150Ti was also significantly greater than on $\mathrm{BCP} 1300(p<0.01)$, at levels similar to BCP1150 at day 4 and 5 (Fig. 7A). These data indicated that the difference in titanium coating had little effect on cell growth; however, the difference in microstructure had a pronounced effect. After $5 \mathrm{~d}$ of culture, cell viability was $\sim 2 \times$ higher on both BCP1150 and BCP1150Ti than on BCP1300 (both $p<0.0001$ ) (Fig. 7B). Further, cell viability was higher for BCP1150Ti than for BCP1150 $(p=0.002)$ (Fig. 7B).

RAW264.7 cell proliferation was analysed on BCP1150 and $\mathrm{BCP} 1300$ by measuring cell viability over time normalised to the viability at the time of seeding (d0) (Fig. 7C). BCP1150Ti was not included in this analysis, focusing only on the effects of surface structure, not surface chemistry. At day 1, cell viability was similar on the materials suggesting that initial cell attachment was equivalent. By day 3, RAW264.7 cell proliferation was significantly greater for BCP1150, resulting in $\sim 2 \times$ greater viability than on $\mathrm{BCP} 1300(p=0.001)$. The same difference in cell viability was maintained through day 4 $(p=0.004)$ and day $5(p=0.005)$, indicating that BCP1150 stimulated significantly more proliferation of RAW264.7 cells than BCP1300 over the entire culture period. In fact, RAW264.7 cells cultured on BCP1300 did not proliferate between 1 and $5 \mathrm{~d}$ in culture (Fig. 7C). To evaluate if interactions with $\mathrm{BCP} 1300$ inhibited the proliferation of other cell types, C2C12 myoblasts were also cultured on the materials, but in contrast, these cells proliferated in typical logarithmic fashion on $\mathrm{BCP} 1300$ and to a greater extent than on BCP1150 by day 4 and 5 ( $p=0.003$ and $p=0.001$, respectively) (Fig. 7D).

In sum, BCP1150 promoted significantly higher cell growth and viability of RAW264.7 (pre-)osteoclasts than BCP1300 in a process that was not adversely affected by 

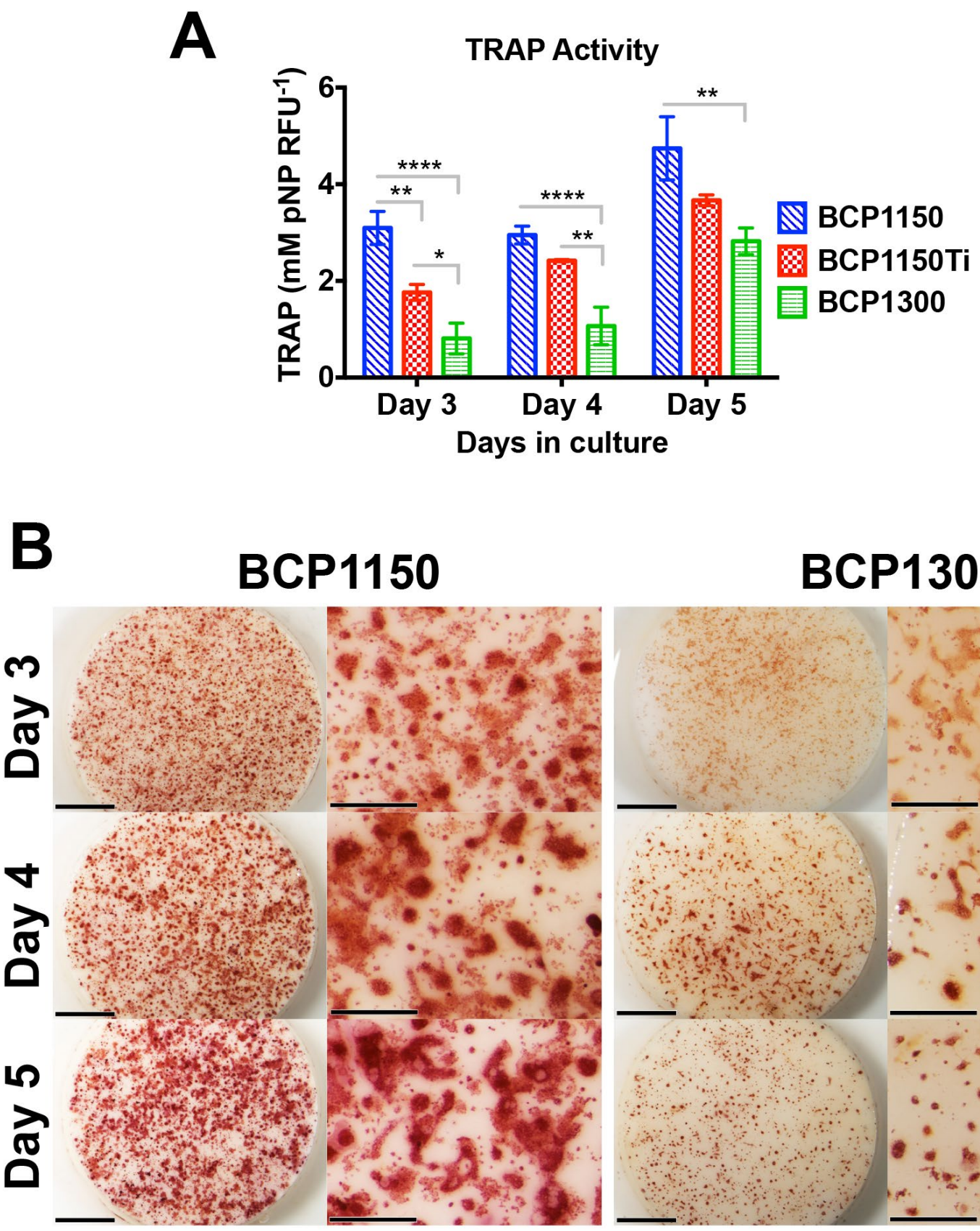

BCP1300

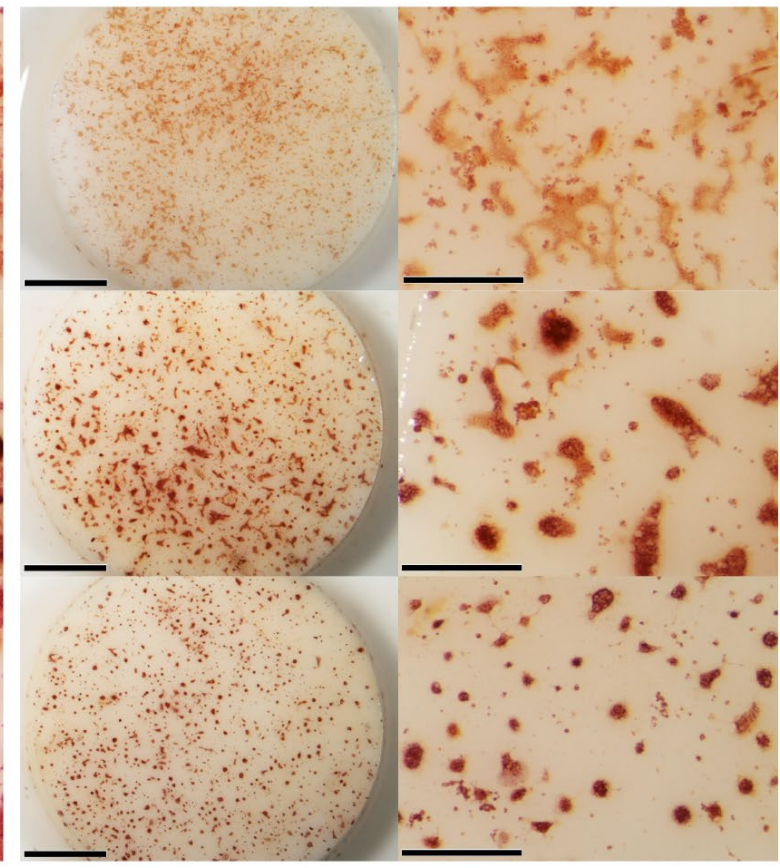

Fig. 8. Tartrate resistant acid phosphatase (TRAP) activity of RAW264.7 osteoclasts cultured on BCP. Biochemical TRAP activity in the cell lysate was significantly higher on BCP1150 than BCP1300 throughout the culture period, as well as BCP1150Ti at day 3 (A). By cytochemical staining, osteoclasts formed on BCP1150 are consistently larger, denser, and more intensely stained than on BCP1300, in agreement with the biochemical assay (overview scale $=2 \mathrm{~mm}$; detail scale $=500 \mu \mathrm{m})(\mathbf{B})$. Visualisation of TRAP staining was not possible on BCP1150Ti discs, due to their dark colour. Biochemical TRAP activity (mM pNP normalised to viable cells, AB RFU) represents the mean \pm S.D. of $n=3$ replicate discs. $* p<0.05, * * p<0.01, * * * * p<0.0001$.

titanium coating; however, this response was not universal to other cell types such as $\mathrm{C} 2 \mathrm{C} 12$ myoblasts.

\section{TRAP activity}

TRAP enzyme activity in the RAW264.7 cells was assayed both biochemically in the cell lysate and cytochemically by staining. Biochemical TRAP activity in the lysate of cells cultured on $\mathrm{BCP} 1150$ was significantly higher than that of BCP1300 at day $3(\sim 4 \times, p<0.0001)$, day $4(\sim 3 \times$, $p<0.0001)$ and day $5(\sim 2 \times, p=0.008)($ Fig. $8 \mathrm{~A})$. Cells cultured on BCP1150Ti also expressed significantly more TRAP activity than BCP1300 at day $3(\sim 2 \times, p=0.023)$ and day $4(\sim 2.5 \times, p=0.002)$, although at day 5 there was no statistical difference $(p=0.194)$. Cellular TRAP activity was different between BCP1150 and BCP1150Ti at day 3 $(\sim 1.8 \times, p=0.004)$; however, by day 4 and 5 there was no statistical difference ( $p=0.144$ and 0.102 , respectively) (Fig. 8A).

To visually confirm the biochemical results, cells were stained for TRAP at the same time points (Fig. 8B). 

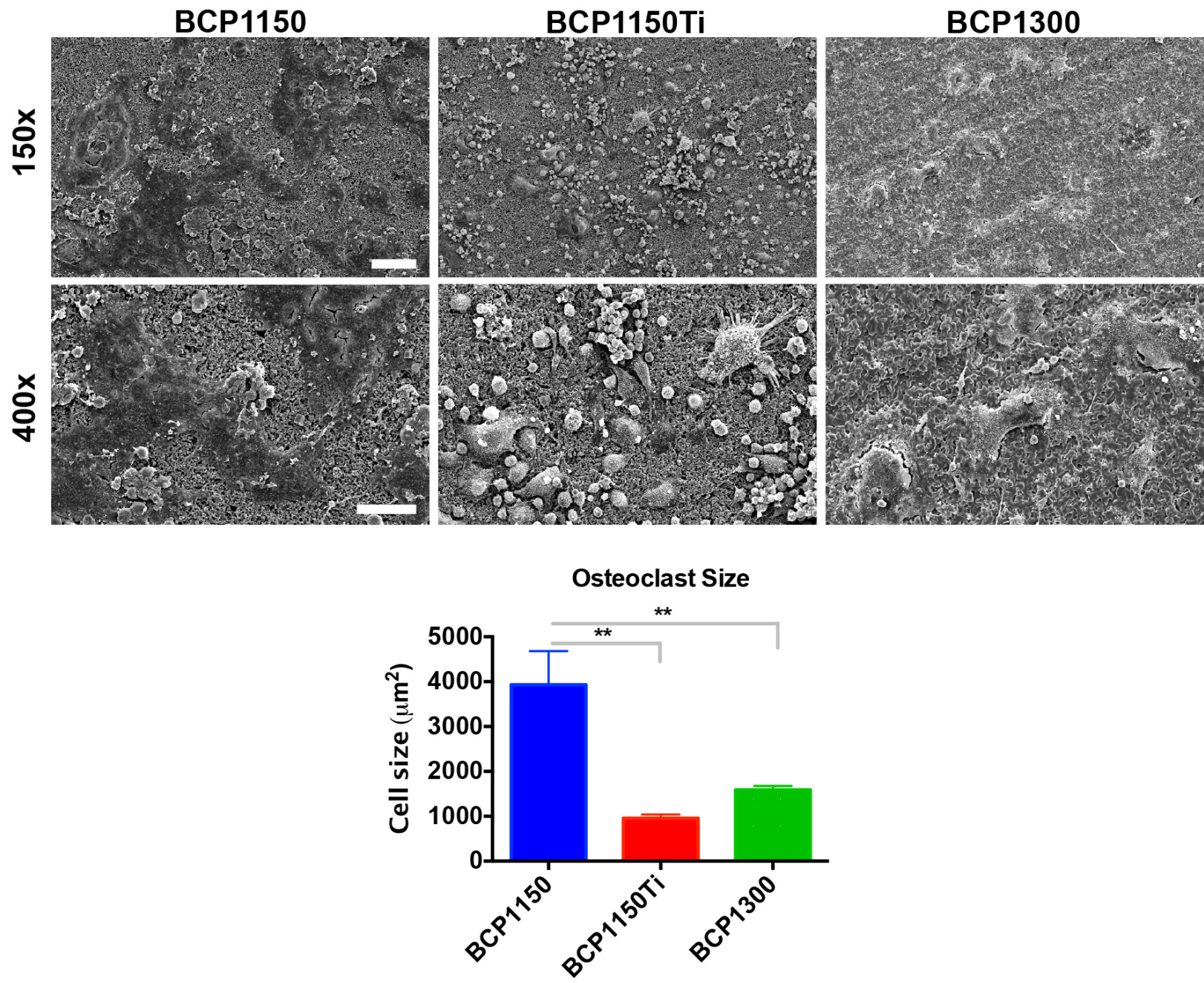

Fig. 9. Scanning electron microscopy (SEM) of osteoclasts formed on BCP. SEM micrographs captured at day 5 show massive networks of fused osteoclasts on BCP1150 (large dark cells), whereas cells were significantly smaller and less fused on BCP1150Ti and BCP1300 $(150 \times$ scale $=100 \mu \mathrm{m} ; 400 \times$ scale $=50 \mu \mathrm{m})$. Osteoclast size data represents the mean \pm S.D. of $n=2$ replicate discs. $* * p<0.01$.

Visualisation of TRAP staining on BCP1150Ti was not possible because of the dark colour of the coating. A clear difference in osteoclast fusion and TRAP activity between BCP1150 and BCP1300 was observed (Fig. 8B): cells were substantially larger and more intensely stained on BCP1150 at all time points. On BCP1150, numerous cellcell junctions were observed between densely distributed cells; in contrast, on BCP1300, cell junctions were sparse likely owing to less cells present (Fig. 8B), in confirmation of the cell viability and DNA assays (Fig. 7).

\section{Osteoclast morphology and size}

Osteoclast morphology and size were analysed by SEM at day 5 , corresponding with the peak of TRAP activity and cell fusion visualised by TRAP staining (Fig. 9). On BCP1150, fused cells were massive $\left(\sim 4,000 \mu \mathrm{m}^{2}\right)$ and tightly attached to the BCP surface in an extensive cell network. Single cells were generally found in clusters, with partially fused cell membranes. In contrast, fused cells on BCP1150Ti were $\sim 75 \%$ smaller $\left(\sim 1,000 \mu \mathrm{m}^{2}, p=0.002\right)$ and appeared rounder and less spread out on the surface. On BCP1300, fused cells were also smaller than on BCP1150 $\left(\sim 1,500 \mu \mathrm{m}^{2}, p=0.008\right)$, and often appeared to be apoptotic or necrotic with deteriorating cell membranes. Fewer cells were present on BCP1300 than BCP1150 and BCP1150Ti, in agreement with the cell viability and DNA assays.

\section{Discussion}

In the present results, $\mathrm{BCP}$ and titanium-coated $\mathrm{BCP}$ with small surface microstructural dimensions $(\sim 1 \mu \mathrm{m})$ promoted osteoclast-like cell formation along with de novo bone formation, while larger surface architecture $(\sim 2-4 \mu \mathrm{m})$ inhibited these effects. Moreover, macro-scale features such as concavities, macropores, or interparticle space were unnecessary to stimulate this response. These in vivo observations were further investigated in vitro using a previously described osteoclastogenesis model (Davison et al., 2014b). Notably, osteoclast survival and differentiation were significantly promoted by the osteoinductive surface structure of BCP1150 and BCP1150Ti versus the non-inductive surface structure of BCP1300. Pre-osteoclast proliferation was also stunted by $\mathrm{BCP} 1300$ versus $\mathrm{BCP} 1150$; however, $\mathrm{C} 2 \mathrm{C} 12$ myoblasts proliferated strongly on BCP1300 versus BCP1150, 
illustrating that BCP1300 was not universally detrimental to cell proliferation. These in vitro results may also explain why few multinucleated cells but abundant soft tissue was present on this surface in vivo. Regarding osteoclast fusion and size, BCP1150 stimulated the formation of large, fused osteoclasts that were $\sim 2-4$ times larger than those formed on either BCP1150Ti or BCP1300 in vitro. In this way, surface microstructural dimensions of $\sim 1 \mu \mathrm{m}$ promoted (pre-)osteoclast proliferation, differentiation, and survival versus larger surface structure, while titanium surface chemistry appeared to limit osteoclast fusion.

At the onset of the present study, it was unclear whether planar, macroscopically flat implants could induce bone formation, based on a lack of direct investigation in the literature (Barradas et al., 2011). Bone formed on the outside surface of the microstructured constructs, not only between the discs; thus, the crucial role of surface microstructure on osteoinduction was more clearly isolated and interparticle space was shown to be dispensable. Still, the amount of ectopic bone formed in the present study was small in comparison to the ectopic bone formed by a similar microstructured BCP with macroporous structure, as previously reported (Habibovic et al., 2006b; Yuan et al., 2010). So, macrostructural features may enhance bone deposition after it has already been triggered by osteoinductive microstructure.

Ectopic bone also formed on the titanium surface of BCP1150Ti indicating that surface chemistry is a flexible parameter in the osteoinductive performance of microstructured materials. Rather than being fully sealed, the line-of-sight sputter deposition of titanium on BCP1150 preserved the chemical reactivity of the BCP substrate and was still intact after implantation. Whereas BCP1150Ti possessed small surface microarchitecture and similar dissolution profile of the underlying BCP1150 substrate, other osteoinductive titanium materials described in the literature possess nano-/microarchitecture (Fujibayashi et al., 2004; Fukuda et al., 2011), and being fully made up of titanium are incapable of releasing calcium or phosphate ions into solution. In a preliminary step toward the development of osteoinductive titanium, Kokubo (1996) showed that alkali followed by thermal treatment of pure titanium resulted in a stabilised microporous surface structure that could form a carbonate apatite layer in vitro and in vivo, and even bond directly to native bone (Kokubo, 1996; Kokubo et al., 1996). Tuning this alkali thermal treatment $(10 \mathrm{M} \mathrm{NaOH}$ to $5 \mathrm{M} \mathrm{NaOH})$ later resulted in a different nano-/microrough surface and the induction of de novo bone (Fujibayashi et al., 2004; Fukuda et al., 2011). However, in these same studies it was found that apatite formation alone was not sufficient to induce ectopic bone formation, despite the positive impact on osseointegration. Similarly, it is known that BCP readily forms a carbonate apatite layer in body fluid (Daculsi et al., 1989; Daculsi et al., 1990), which we also confirmed for BCP1150 and BCP1300 in simulated body fluid (data not shown); however, only BCP1150 - and now BCP1150Ti with equivalent microstructure - can induce ectopic bone formation. In agreement with the conclusion of Fujibayashi et al. (2004), we propose that these differences hinge on microarchitecture (i.e., topography) although apatite formation is likely a prerequisite for osteoinduction to take place because of its importance for bone-bonding. Considering that collagen fibres also infiltrate a microporous, osteoinductive surface before de novo bone formation (Kondo et al., 2006), apatite formation and microarchitecture may synergise to provide a biomimetic template for both phases of bone tissue.

Because BCP1150, BCP1150Ti and BCP1300 all shared similar $\mathrm{Ca}^{2+}$ and $\mathrm{P}_{\mathrm{i}}$ release profiles in vitro, the differences in bone formation are difficult to explain in terms of intrinsic differences in surface reactivity or $\mathrm{Ca}^{2+} / \mathrm{P}_{i}$ signalling. However, this in vitro characterisation is limited in light of the physico-chemical complexity of body fluid in vivo, including supersaturated $\mathrm{Ca}^{2+} / \mathrm{P}_{\mathrm{i}}$ levels as well as blood serum (Garnett and Dieppe, 1990). Other theories on osteoinduction speculate that material degradation by osteoclast resorption or macrophage phagocytosis may independently speed the dissolution/precipitation of a bioactive carbonate apatite layer (LeGeros, 1993), establish an instructive geometric template for de novo bone formation in resorption lacunae along with increased local $\mathrm{Ca}^{2+}$ concentrations (Klar et al., 2013; Ripamonti et al., 2008; Wilkinson et al., 2011), or liberate crystalline nano-/microparticulate and a subsequent osteogenic cytokine cascade (Gauthier et al., 1999; Malard et al., 1999; Velard et al., 2013). However, in the present study neither characteristic osteoclast resorption lacunae nor degraded $\mathrm{BCP}$ particulate were apparent in the histology.

Alternatively, decades of research have shown that surface topography can directly stimulate bone cell differentiation and function on various material substrates, including polymers (Fu et al., 2010; Watari et al., 2012; Wilkinson et al., 2011; You et al., 2010), titanium (Brunette, 1988; Gittens et al., 2011; McNamara et al., 2011), ceramics (Webster, 2000; Zhang et al., 2014), and tissue (Gray et al., 1996). Topographical control of cell fate is a complex phenomenon that can occur through focal adhesion clustering and downstream focal adhesion kinase (FAK) signalling (McNamara et al., 2010). This cascade is initiated when cell surface integrins bind matrix proteins adsorbed to the substrate (Chou et al., 1995; Stevens and George, 2005), so protein adsorption from the body fluid may play a crucial role in the differences in cell-surface interactions observed in the present study. Indeed, our previous experiments showed that microstructured BCP1150 adsorbs more proteins than denser BCP1300 (Yuan et al., 2010).

With respect to the role of osteoclasts in osteoinduction, the present study further substantiates a link between microstructure, osteoclastogenesis, and eventual de novo bone formation. We previously reported similar findings using TCP with two different surface structures, analogous to BCP1150 and BCP1300 investigated in the present study (Davison et al., 2014b; Zhang et al., 2014). TCP possessing surface microstructural dimensions $\leq 1 \mu \mathrm{m}$ (TCPs) was extensively colonised by multinucleated osteoclast-like cells adjacent to substantial amounts of ectopic bone in the muscle tissue of dogs after 12 weeks. In contrast, TCP with larger surface structural dimensions $(\sim 2-4 \mu \mathrm{m}, \mathrm{TCPb})$ contained few multinucleated cells and formed no ectopic bone. Moreover, TCPs significantly promoted osteoclast 
differentiation and fusion versus $\mathrm{TCPb}$ using the same in vitro osteoclastogenesis model applied in the present study (Davison et al., 2014b). Taking these previous and current results together, it can be concluded that for both $\mathrm{BCP}$ and TCP - representing the most frequently investigated osteoinductive materials in the literature (Barradas et al., 2011) - surface microstructural dimensions of $\sim 1 \mu \mathrm{m}$ robustly promoted the formation of osteoclast-like cells concurrent with de novo bone formation. These results add to the growing consensus that osteoclast formation is prerequisite for osteoinduction (Davison et al., 2014a; Klar et al., 2013; Kondo et al., 2006; Le Nihouannen et al., 2005); however, it is still unknown what the exact role of osteoclasts is in this process.

It has also been suggested that CaPs may stimulate bone formation by absorbing BMPs (bone morphogenetic proteins) endogenously synthesised near the implant surface (Klar et al., 2014; Ripamonti et al., 1993) or circulating in the blood (de Groot, 1998). However, large doses of BMPs are required to stimulate substantial amounts of de novo bone formation, likely rendering basal levels of BMPs circulating in the blood ineffective in achieving this response (van Baardewijk et al., 2013; Yuan et al., 2010). Alternatively, BMPs or other osteogenic factors may originate from (pre-)osteoclast interactions with microstructured surfaces including $\mathrm{CaP}$ (Davison et al., 2014b) and titanium (Takebe et al., 2003). Elevated $\mathrm{Ca}^{2+}$ levels resulting from osteoclast resorption of a mineralised substrate can also stimulate BMP expression of precursor cells (Barradas et al., 2012; Klar et al., 2013). In support of this, osteoclast depletion by bisphosphonate treatment attenuated BMP2 expression in osteoinductive $\mathrm{CaP}$ implants and limited ectopic bone formation (Klar et al., 2013), potentially because osteoclasts synthesise a variety of BMPs (Garimella et al., 2008). Moreover, treatment with noggin, which blocks BMP binding to its membrane-bound receptor, also stunted ectopic bone formation by an osteoinductive CaP (Klar et al., 2014). However, chondrogenesis was not reported in either of these studies (Klar et al., 2013; Klar et al., 2014), or in a thorough review of osteoinductive materials research (Barradas et al., 2011), suggesting that osteoinduction may not proceed via a classical BMP-induced endochondral pathway. In the broader context of bone metabolism, activated (pre-)osteoclasts secrete a variety of other nonBMP osteogenic factors - e.g., Wnts, S1P, OSM, and CTHRC1 - resulting in osteoblast differentiation of local precursors (Garimella et al., 2008; Guihard et al., 2012; Pederson et al., 2008; Takeshita et al., 2013) through intramembranous ossification (Durmus et al., 2006). To elucidate the mechanism of osteoinduction, more research is needed to discern the distinct molecular pathways governing endochondral versus intramembranous ossification over the entire time course of ectopic bone formation.

To challenge the theory that osteoclast formation promoted by surface (sub)microstructure is instrumental for osteoinduction, osteoclastogenesis on other osteoinductive materials should be investigated. If, for example, microstructured HA and titanium also promoted osteoclastogenesis and ectopic bone in contrast to their non-microstructured controls, a broader link between osteoclast formation and de novo bone formation would be further substantiated. Pending deeper biological insight, it may be possible to anticipate osteoinductive performance based on simplified in vitro osteoclastogenesis models. And, if osteoclasts are not only requisite but also directive in de novo bone formation through the secretion of trophic factors, locally stimulating osteoclastogenesis (i.e., controlled release of RANKL) may even render nonmicrostructured CaPs osteoinductive.

\section{Conclusion}

BCP1150 and titanium-coated BCP1150Ti possessing small surface microstructure $(\sim 1 \mu \mathrm{m})$ formed ectopic bone adjacent to multinucleated osteoclast-cells in the muscle of dogs. Implants were in the form of planar discs so macro-scale features such as concavities, macropores and interparticle space were unnecessary for this response. In contrast, $\mathrm{BCP} 1300$ with identical compositional chemistry but larger surface architecture $(\sim 2-4 \mu \mathrm{m})$ formed neither osteoclast-like cells nor ectopic bone; it was instead encapsulated by fibrous tissue. Similar to the in vivo results, (pre-)osteoclast proliferation and differentiation were significantly promoted by BCP 1150 and BCP $1150 \mathrm{Ti}$ versus $\mathrm{BCP} 1300$ in vitro; moreover, osteoclasts were larger and more fused on $\mathrm{BCP} 1150$ versus either BCP1150Ti or $\mathrm{BCP} 1300$. Together, these in vitro and in vivo results indicate that (sub)micron-scale surface architecture is the crucial material parameter versus macrostructure or surface chemistry in stimulating both osteoclastogenesis and ectopic bone formation in a related process.

\section{Acknowledgements}

The authors gratefully acknowledge the support of the TeRM Smart Mix Program of the Netherlands Ministry of Economic Affairs and the Netherlands Ministry of Education, Culture and Science. This research forms part of the Project P2.04 BONE-IP of the research program of the Biomedical Materials Institute, co-funded by the Dutch Ministry of Economic Affairs. This work was also supported by funding under the Seventh Research Framework Program of the European Union, through the project REBORNE under Grant agreement no. 241879. Special thanks are due to Dr. Zeinab Tahmasebi Birgani (MIRA) for her technical expertise with EDS. We wish to confirm that there are no known conflicts of interest associated with this publication and there has been no significant financial support for this work that could have influenced its outcome.

\section{References}

Ahmed SA, Gogal RM, Walsh JE (1994) A new rapid and simple non-radioactive assay to monitor and determine the proliferation of lymphocytes: an alternative to $[3 \mathrm{H}]$ 
thymidine incorporation assay. J Immunol Methods 170: 211-224.

Akiyama N, Takemoto M, Fujibayashi S, Neo M, Hirano M, Nakamura T (2011) Difference between dogs and rats with regard to osteoclast-like cells in calciumdeficient hydroxyapatite-induced osteoinduction. J Biomed Mater Res A 96: 402-412.

Barradas AMC, Yuan H, van Blitterswijk CA, Habibovic P (2011) Osteoinductive biomaterials: current knowledge of properties, experimental models and biological mechanisms. Eur Cell Mater 21: 407-429.

Barradas AMC, Fernandes HAM, Groen N, Chai YC, Schrooten J, van de Peppel J, van Leeuwen JPTM, van Blitterswijk CA, de Boer J (2012) A calcium-induced signaling cascade leading to osteogenic differentiation of human bone marrow-derived mesenchymal stromal cells. Biomaterials 33: 3205-3215.

Barradas AMC, Monticone V, Hulsman M, Danoux C, Fernandes H, Tahmasebi Birgani Z, Barrère-de Groot F, Yuan H, Reinders M, Habibovic P, van Blitterswijk C, de Boer J (2013) Molecular mechanisms of biomaterial-driven osteogenic differentiation in human mesenchymal stromal cells. Integr Biol 5: 920-931.

Baslé MF, Chappard D, Grizon F, Filmon R, Delecrin J, Daculsi G, Rebel A (1993) Osteoclastic resorption of Ca-P biomaterials implanted in rabbit bone. Calcif Tissue Int 53: 348-356.

Beck GR, Zerler B, Moran E (2000) Phosphate is a specific signal for induction of osteopontin gene expression. Proc Natl Acad Sci USA 97: 8352-8357.

Benahmed M, Bouler JM, Heymann D, Gan O, Daculsi G (1996) Biodegradation of synthetic biphasic calcium phosphate by human monocytes in vitro: a morphological study. Biomaterials 17: 2173-2178.

Bongio M, van den Beucken JJJ, Nejadnik MR, Tahmasebi Birgani Z, Habibovic P, Kinard LA, Kasper FK, Mikos AG, Leeuwenburgh SCG, Jansen JA (2013) Subcutaneous tissue response and osteogenic performance of calcium phosphate nanoparticle-enriched hydrogels in the tibial medullary cavity of guinea pigs. Acta Biomater 9: 5464-5474.

Brunette DM (1988) The effects of implant surface topography on the behavior of cells. Int J Oral Maxillofac Implants 3: 231-246.

Chou L, Firth JD, Uitto VJ, Brunette DM (1995) Substratum surface topography alters cell shape and regulates fibronectin mRNA level, mRNA stability, secretion and assembly in human fibroblasts. J Cell Sci 108: 1563-1573.

Collin-Osdoby P, Yu X, Zheng H, Osdoby P (2003) RANKL-mediated osteoclast formation from murine RAW 264.7 cells. Methods Mol Med 80: 153-166.

Curran JM, Chen R, Hunt JA (2006) The guidance of human mesenchymal stem cell differentiation in vitro by controlled modifications to the cell substrate. Biomaterials 27: 4783-4793.

Daculsi G, LeGeros RZ, Nery E, Lynch K, Kerebel B (1989) Transformation of biphasic calcium phosphate ceramics in vivo: ultrastructural and physicochemical characterization. J Biomed Mater Res 23: 883-894.
Daculsi G, LeGeros RZ, Heughebaert M, Barbieux I (1990) Formation of carbonate-apatite crystals after implantation of calcium phosphate ceramics. Calcif Tissue Int 46: 20-27.

Davison NL, Gamblin A-L, Layrolle P, Yuan H, de Bruijn JD, Barrère-de Groot F (2014a) Liposomal clodronate inhibition of osteoclastogenesis and osteoinduction by submicrostructured beta-tricalcium phosphate. Biomaterials 35: 5088-5097.

Davison NL, Luo X, Schoenmaker T, Everts V, Yuan H, Barrère-de Groot F, de Bruijn JD (2014b) Submicronscale surface architecture of tricalcium phosphate directs osteogenesis in vitro and in vivo. Eur Cell Mater 27: 281297.

de Groot K (1998) Carriers that concentrate native bone morphogenetic protein in vivo. Tissue Eng 4: 337-341.

Durmus T, LeClair RJ, Park KS, Terzic A, Yoon JK, Lindner V (2006) Expression analysis of the novel gene collagen triple helix repeat containing-1 (Cthrc1). Gene Expr Patterns 6: 935-940.

Fellah BH, Josselin N, Chappard D, Weiss P, Layrolle P (2007) Inflammatory reaction in rats muscle after implantation of biphasic calcium phosphate micro particles. J Mater Sci Mater Med 18: 287-294.

Fu J, Wang Y, Yang MT, Desai RA, Yu X, Liu Z, Chen CS (2010) Mechanical regulation of cell function with geometrically modulated elastomeric substrates. Nat Methods 7: 733-736.

Fujibayashi S, Neo M, Kim H-M, Kokubo T, Nakamura $\mathrm{T}$ (2004) Osteoinduction of porous bioactive titanium metal. Biomaterials 25: 443-450.

Fukuda A, Takemoto M, Saito T, Fujibayashi S, Neo M, Pattanayak DK, Matsushita T, Sasaki K, Nishida N, Kokubo T, Nakamura T (2011) Osteoinduction of porous Ti implants with a channel structure fabricated by selective laser melting. Acta Biomater 7: 2327-2336.

Garimella R, Tague SE, Zhang J, Belibi F, Nahar N, Sun BH, Insogna K, Wang J, Anderson HC (2008) Expression and synthesis of bone morphogenetic proteins by osteoclasts : a possible path to anabolic bone remodeling J Histochem Cytochem 56: 569-577.

Garnett J, Dieppe P (1990) The effects of serum and human albumin on calcium hydroxyapatite crystal growth. Biochem J 266: 863-868.

Gauthier O, Bouler JM, Weiss P, Bosco J, Daculsi G, Aguado E (1999) Kinetic study of bone ingrowth and ceramic resorption associated with the implantation of different injectable calcium-phosphate bone substitutes. J Biomed Mater Res 47: 28-35.

Gauthier O, Müller R, von Stechow D, Lamy B, Weiss P, Bouler J-M, Aguado E, Daculsi G (2005) In vivo bone regeneration with injectable calcium phosphate biomaterial: a three-dimensional micro-computed tomographic, biomechanical and SEM study. Biomaterials 26: 5444-5453.

Gittens RA, McLachlan T, Olivares-Navarrete R, Cai Y, Berner S, Tannenbaum R, Schwartz Z, Sandhage KH, Boyan BD (2011) The effects of combined micron-/ submicron-scale surface roughness and nanoscale features on cell proliferation and differentiation. Biomaterials 32: 3395-3403. 
Gloeckner H, Jonuleit T, Lemke HD (2001) Monitoring of cell viability and cell growth in a hollow-fiber bioreactor by use of the dye Alamar Blue. J Immunol Methods 252: 131-138.

Gray C, Boyde A, Jones SJ (1996) Topographically induced bone formation in vitro: implications for bone implants and bone grafts. Bone 18: 115-123.

Guihard P, Danger Y, Brounais B, David E, Brion R, Delecrin J, Richards CD, Chevalier S, Rédini F, Heymann D, Gascan H, Blanchard F (2012) Induction of osteogenesis in mesenchymal stem cells by activated monocytes/ macrophages depends on oncostatin $\mathrm{m}$ signaling. Stem Cells 30: 762-772.

Habibovic P, Li J, van der Valk CM, Meijer G, Layrolle P, van Blitterswijk CA, de Groot K (2005a) Biological performance of uncoated and octacalcium phosphatecoated Ti6Al4V. Biomaterials 26: 23-36.

Habibovic P, Yuan H, van der Valk CM, Meijer G, van Blitterswijk CA, de Groot K (2005b) 3D microenvironment as essential element for osteoinduction by biomaterials. Biomaterials 26: 3565-3575.

Habibovic P, Sees TM, van den Doel MA, van Blitterswijk CA, de Groot K (2006a) Osteoinduction by biomaterials--physicochemical and structural influences. J Biomed Mater Res A 77: 747-762.

Habibovic P, Yuan H, van den Doel M, Sees TM, van Blitterswijk CA, de Groot K (2006b) Relevance of osteoinductive biomaterials in critical-sized orthotopic defect. J Orthop Res 24: 867-876.

Halleen JM, Alatalo SL, Janckila AJ, Woitge HW, Seibel MJ, Väänänen HK (2001) Serum tartrate-resistant acid phosphatase $5 \mathrm{~b}$ is a specific and sensitive marker of bone resorption. Clin Chem 47: 597-600.

Klar RM, Duarte R, Dix-Peek T, Dickens C, Ferretti C, Ripamonti U (2013) Calcium ions and osteoclastogenesis initiate the induction of bone formation by coral-derived macroporous constructs. J Cell Mol Med 17: 1444-1457.

Klar RM, Duarte R, Dix-Peek T, Ripamonti U (2014) The induction of bone formation by the recombinant human transforming growth factor- $\beta 3$. Biomaterials 35: 2773-2788.

Kokubo T (1996) Formation of biologically active bone-like apatite on metals and polymers by a biomimetic process. Thermochim Acta 280-281: 479-490.

Kokubo T, Miyaji F, Kim H-M, Nakamura T (1996) Spontaneous formation of bonelike apatite layer on chemically treated titanium metals. J Am Ceram Soc 79: 1127-1129.

Kondo N, Ogose A, Tokunaga K, Umezu H, Arai K, Kudo N, Hoshino M, Inoue H, Irie H, Kuroda K, Mera H, Endo N (2006) Osteoinduction with highly purified beta-tricalcium phosphate in dog dorsal muscles and the proliferation of osteoclasts before heterotopic bone formation. Biomaterials 27: 4419-4427.

LeGeros RZ (1993) Biodegradation and bioresorption of calcium phosphate ceramics. Clin Mater 14: 65-88.

LeGeros RZ (2008) Calcium phosphate-based osteoinductive materials. Chem Rev 108: 4742-4753.
Le Nihouannen D, Daculsi G, Saffarzadeh A, Gauthier O, Delplace S, Pilet P, Layrolle P (2005) Ectopic bone formation by microporous calcium phosphate ceramic particles in sheep muscles. Bone 36: 1086-1093.

Ljusberg J, Ek-Rylander B, Andersson G (1999) Tartrate-resistant purple acid phosphatase is synthesized as a latent proenzyme and activated by cysteine proteinases. Biochem J 343: 63-69.

Magan A, Ripamonti U (1996) Geometry of porous hydroxyapatite implants influences osteogenesis in baboons (Papio ursinus). J Craniofac Surg 7: 71-78.

Makihira S, Mine Y, Kosaka E, Nikawa H (2007) Titanium surface roughness accelerates RANKLdependent differentiation in the osteoclast precursor cell line, RAW264. 7. Dent Mater J 26: 739-745.

Malard O, Bouler JM, Guicheux J, Heymann D, Pilet P, Coquard C, Daculsi G (1999) Influence of biphasic calcium phosphate granulometry on bone ingrowth, ceramic resorption, and inflammatory reactions: preliminary in vitro and in vivo study. J Biomed Mater Res 46: 103-111.

McNamara LE, McMurray RJ, Biggs MJP, Kantawong F, Oreffo ROC, Dalby MJ (2010) Nanotopographical control of stem cell differentiation. J Tissue Eng 2010: 120623 .

McNamara LE, Sjöström T, Burgess KE V, Kim JJW, Liu E, Gordonov S, Moghe P V, Meek RMD, Oreffo ROC, Su B, Dalby MJ (2011) Skeletal stem cell physiology on functionally distinct titania nanotopographies. Biomaterials 32: 7403-7410.

Nakayama GR, Caton MC, Nova MP, Parandoosh Z (1997) Assessment of the Alamar Blue assay for cellular growth and viability in vitro. J Immunol Methods 204: 205-208.

Pederson L, Ruan M, Westendorf JJ, Khosla S, Oursler MJ (2008) Regulation of bone formation by osteoclasts involves Wnt/BMP signaling and the chemokine sphingosine-1-phosphate. Proc Natl Acad Sci USA 105: 20764-20769.

Ripamonti U (1991) The morphogenesis of bone in replicas of porous hydroxyapatite obtained from conversion of calcium carbonate exoskeletons of coral. J Bone Joint Surg Am 73: 692-703.

Ripamonti U, van den Heever B, van Wyk J (1993) Expression of the osteogenic phenotype in porous hydroxyapatite implanted extraskeletally in baboons. Matrix 13: 491-502.

Ripamonti U, Richter PW, Nilen RWN, Renton L (2008) The induction of bone formation by smart biphasic hydroxyapatite tricalcium phosphate biomimetic matrices in the non-human primate Papio ursinus. J Cell Mol Med 12: 2609-2621.

Ripamonti U, Klar RM, Renton LF, Ferretti C (2010) Synergistic induction of bone formation by hOP-1, hTGFbeta3 and inhibition by zoledronate in macroporous coralderived hydroxyapatites. Biomaterials 31: 6400-6410.

Stevens MM, George JH (2005) Exploring and engineering the cell surface interface. Science 310: 1135 1138 . 
Syed-Picard FN, Jayaraman T, Lam RSK, Beniash E, Sfeir C (2013) Osteoinductivity of calcium phosphate mediated by connexin 43. Biomaterials 34: 3763-3774.

Takahashi N, Udagawa N, Kobayashi Y, Suda T (2007) Generation of osteoclasts in vitro, and assay of osteoclast activity. Methods Mol Med 135: 285-301.

Takebe J, Champagne CM, Offenbacher S, Ishibashi K, Cooper LF (2003) Titanium surface topography alters cell shape and modulates bone morphogenetic protein 2 expression in the J774A. 1 macrophage cell line. J Biomed Mater Res A 64: 207-216.

Takeshita S, Fumoto T, Matsuoka K, Park K, Aburatani H, Kato S, Ito M, Ikeda K (2013) Osteoclast-secreted CTHRC1 in the coupling of bone resorption to formation. J Clin Invest 123: 3914-3924.

van Baardewijk LJ, van der Ende J, LissenbergThunnissen S, Romijn LM, Hawinkels LJAC, Sier CFM, Schipper IB (2013) Circulating bone morphogenetic protein levels and delayed fracture healing. Int Orthop 37: 523-527.

Velard F, Braux J, Amedee J, Laquerriere P (2013) Inflammatory cell response to calcium phosphate biomaterial particles: an overview. Acta Biomater 9: 49564963.

Vlacic-Zischke J, Hamlet SM, Friis T, Tonetti MS, Ivanovski S (2011) The influence of surface microroughness and hydrophilicity of titanium on the up-regulation of TGF $\beta / \mathrm{BMP}$ signalling in osteoblasts. Biomaterials 32: 665-671.

Watari S, Hayashi K, Wood JA, Russell P, Nealey PF, Murphy CJ, Genetos DC (2012) Modulation of osteogenic differentiation in hMSCs cells by submicron topographically-patterned ridges and grooves. Biomaterials 33: $128-136$.

Webster T (2000) Enhanced functions of osteoblasts on nanophase ceramics. Biomaterials 21: 1803-1810.

Webster TJ, Ergun C, Doremus RH, Siegel RW, Bizios R (2001) Enhanced osteoclast-like cell functions on nanophase ceramics. Biomaterials 22: 1327-1333.

Wilkinson A, Hewitt RN, McNamara LE, McCloy D, Dominic Meek RM, Dalby MJ (2011) Biomimetic microtopography to enhance osteogenesis in vitro. Acta Biomater 7: 2919-2925.

Wolke JG, de Groot K, Jansen JA (1998) In vivo dissolution behavior of various RF magnetron sputtered Ca-P coatings. J Biomed Mater Res 39: 524-530.
Yamada S, Heymann D, Bouler JM, Daculsi G (1997) Osteoclastic resorption of calcium phosphate ceramics with different hydroxyapatite/beta-tricalcium phosphate ratios. Biomaterials 18: 1037-1041.

Yamasaki H, Sakai H (1992) Osteogenic response to porous hydroxyapatite ceramics under the skin of dogs. Biomaterials 13: 308-312.

You M-H, Kwak MK, Kim D-H, Kim K, Levchenko A, Kim D-Y, Suh K-Y (2010) Synergistically enhanced osteogenic differentiation of human mesenchymal stem cells by culture on nanostructured surfaces with induction media. Biomacromolecules 11: 1856-1862.

Yuan H, de Bruijn JD (2011) Osteoinductive calcium phosphates. United States Patent 7,942,934 B2: 1-27.

Yuan H, Yang Z, Li Y, Zhang X, de Bruijn JD, de Groot K (1998) Osteoinduction by calcium phosphate biomaterials. J Mater Sci Mater Med 9: 723-726.

Yuan H, Kurashina K, de Bruijn JD, Li Y, de Groot K, Zhang X (1999) A preliminary study on osteoinduction of two kinds of calcium phosphate ceramics. Biomaterials 20: $1799-1806$.

Yuan H, van den Doel M, Li S, Van Blitterswijk CA, de Groot K, de Bruijn JD (2002) A comparison of the osteoinductive potential of two calcium phosphate ceramics implanted intramuscularly in goats. J Mater Sci Mater Med 13: 1271-1275.

Yuan H, Fernandes H, Habibovic P, de Boer J, Barradas AMC, de Ruiter A, Walsh WR, van Blitterswijk CA, de Bruijn JD (2010) Osteoinductive ceramics as a synthetic alternative to autologous bone grafting. Proc Natl Acad Sci USA 107: 13614-13619.

Zhang J, Luo X, Barbieri D, Barradas AMC, de Bruijn JD, van Blitterswijk CA, Yuan H (2014) The size of surface microstructures as an osteogenic factor in calcium phosphate ceramics. Acta Biomater 10: 3254-3263.

Zhao G, Raines AL, Wieland M, Schwartz Z, Boyan BD (2007) Requirement for both micron- and submicron scale structure for synergistic responses of osteoblasts to substrate surface energy and topography. Biomaterials 28: 2821-2829.

Editor's Note: All questions/comments by the reviewers were answered by text changes. There is hence no Discussion with Reviewers section. 